\title{
Model inter-comparison between statistical and dynamic model assessments of the long-term stability of blanket peat in Great Britain (1940-2099)
}

\author{
J. M. Clark ${ }^{1, *}$, M. F. Billett, M. Coyle, S. Croft, S. Daniels, C. D. Evans, \\ M. Evans, C. Freeman, A. V. Gallego-Sala, A. Heinemeyer, J. I. House, \\ D. T. Monteith, D. Nayak, H. G. Orr, I. C. Prentice, R. Rose, J. Rowson, \\ J. U. Smith, P. Smith, Y. M. Tun, E. Vanguelova, F. Wetterhall, F. Worrall
}

${ }^{1}$ Grantham Institute for Climate Change Fellow, Civil and Environmental Engineering, Imperial College London, South Kensington, London SW7 2AZ, UK

\begin{abstract}
We compared output from 3 dynamic process-based models (DMs: ECOSSE, MILLENNIA and the Durham Carbon Model) and 9 bioclimatic envelope models (BCEMs; including BBOG ensemble and PEATSTASH) ranging from simple threshold to semi-process-based models. Model simulations were run at 4 British peatland sites using historical climate data and climate projections under a medium (A1B) emissions scenario from the 11-RCM (regional climate model) ensemble underpinning UKCP09. The models showed that blanket peatlands are vulnerable to projected climate change; however, predictions varied between models as well as between sites. All BCEMs predicted a shift from presence to absence of a climate associated with blanket peat, where the sites with the lowest total annual precipitation were closest to the presence/absence threshold. DMs showed a more variable response. ECOSSE predicted a decline in net $\mathrm{C}$ sink and shift to net $\mathrm{C}$ source by the end of this century. The Durham Carbon Model predicted a smaller decline in the net C sink strength, but no shift to net C source. MILLENNIA predicted a slight overall increase in the net C sink. In contrast to the BCEM projections, the DMs predicted that the sites with coolest temperatures and greatest total annual precipitation showed the largest change in carbon sinks. In this model inter-comparison, the greatest variation in model output in response to climate change projections was not between the BCEMs and DMs but between the DMs themselves, because of different approaches to modelling soil organic matter pools and decomposition amongst other processes. The difference in the sign of the response has major implications for future climate feedbacks, climate policy and peatland management. Enhanced data collection, in particular monitoring peatland response to current change, would significantly improve model development and projections of future change.
\end{abstract}

KEY WORDS: Peatland $\cdot$ Carbon $\cdot$ Climate change $\cdot$ Bioclimatic envelope model $\cdot$ Dynamic model Uplands $\cdot$ ECOSSE $\cdot$ MILLENNIA $\cdot$ Durham carbon model

\section{INTRODUCTION}

Recent observations of a decline in soil organic carbon (SOC; abbreviations used in this article are also defined in Table 1) stocks in England and Wales (Bellamy et al. 2005) and increased dissolved organic carbon (DOC) concentrations in upland surface waters (Freeman et al. 2001a, Monteith et al. 2007) have prompted great interest in soil conservation and restoration in Great Britain. Particular attention has been given to blanket peats as these soils are the most significant terrestrial carbon stores in Great Britain (Milne \& Brown 1997, Billett et al. 2010, this Special) and many areas have been degraded by a long history of land management and pollution (Ramchunder et al. 2009). 
Blanket peat formation is dependent on a positive water balance that is favoured by cooler and wetter conditions (Wieder \& Vitt 2006); therefore, climate change could provide an additional risk to peat stability, which in turn could provide a positive feedback to

Table 1. List of abbrevations

\begin{tabular}{|c|c|}
\hline Abbreviation & Definition \\
\hline AAMWD & $\begin{array}{l}\text { Annual accumulated monthly water deficit } \\
\text { (see Clark et al. 2010) }\end{array}$ \\
\hline $\mathrm{AC}$ & Auchencorth Moss peatland site \\
\hline AET & Actual evapotranspiration \\
\hline AWS & Automatic Weather Station \\
\hline BADC & British Atmospheric Data Centre \\
\hline BBOG & $\begin{array}{l}\text { British Blanket Bog BCEM (see Clark et al. } \\
(2010)\end{array}$ \\
\hline BBOG-GAM & $\begin{array}{l}\text { British Blanket Bog BCEM constructed } \\
\text { using a generalised additive model (see } \\
\text { Clark et al. 2010) }\end{array}$ \\
\hline BBOG-GLM & $\begin{array}{l}\text { British Blanket Bog BCEM constructed } \\
\text { using a generalised linear model (see } \\
\text { Clark et al. 2010) }\end{array}$ \\
\hline BBOG-TREE & $\begin{array}{l}\text { British Blanket Bog BCEM constructed } \\
\text { using a classification tree model (see } \\
\text { Clark et al. 2010) }\end{array}$ \\
\hline BCEM & Bioclimatic envelope model \\
\hline BK & Bleaklow peatland site \\
\hline $\mathrm{CEH}$ & Centre for Ecology and Hydrology \\
\hline $\mathrm{CH}_{4}$ & Methane \\
\hline $\mathrm{CW}$ & Conwy peatland site \\
\hline DIC & Dissolved inorganic carbon \\
\hline $\mathrm{DM}$ & $\begin{array}{l}\text { Dynamic model (ECOSSE, MILLENNIA, } \\
\text { Durham Carbon Model) }\end{array}$ \\
\hline DOC & Dissolved organic carbon \\
\hline ECOSSE & $\begin{array}{l}\text { Estimating Carbon in Organic Soils } \\
\text { Sequestration and Emission, dynamic } \\
\text { model for organic soils (see Smith et al. } \\
2010 \mathrm{a}, \mathrm{b} \text { ) }\end{array}$ \\
\hline GCM & Global climate model \\
\hline GPP & Gross primary production \\
\hline HadRM3 & $\begin{array}{l}\text { Hadley Centre Regional Climate Model } \\
\text { version } 3\end{array}$ \\
\hline H-GLM & Peatland BCEM after Hossell et al. (2000) \\
\hline HOST & Hydrology of soil types (see Table 2) \\
\hline LM & Peatland BCEM after Lindsay et al. (1998) \\
\hline MH & Moor House peatland site \\
\hline MILLENNIA & $\begin{array}{l}\text { Dynamic peatland model (see Heinemeyer } \\
\text { et al. 2010) }\end{array}$ \\
\hline MOS & Model output statistics \\
\hline NPP & Net primary production \\
\hline P50 & $\begin{array}{l}\text { Peatland BCEM adapted after Pearsall } \\
(1950)\end{array}$ \\
\hline P65 & $\begin{array}{l}\text { Peatland BCEM adapted after Pearsall } \\
\text { (1965) }\end{array}$ \\
\hline $\mathrm{PE}$ & Potential evaporation \\
\hline PEATSTASH & Peatland BCEM \\
\hline PFT & Plant functional type \\
\hline POC & Particulate organic carbon \\
\hline $\mathrm{RCM}$ & Regional climate model \\
\hline RothC & $\begin{array}{l}\text { Rothamsted Carbon Model (Coleman \& } \\
\text { Jenkinson 1996) }\end{array}$ \\
\hline SOC & Soil organic carbon \\
\hline SOM & Soil organic matter \\
\hline TMI & Thornthwaite-Mather moisture index \\
\hline UKCP09 & $\begin{array}{l}\text { United Kingdom Climate Projections } \\
2009\end{array}$ \\
\hline
\end{tabular}

climate change by releasing stored SOC to the atmosphere (Limpens et al. 2008). The impact of climate change on the overall net carbon (C) balance is uncertain, as both increases and decreases in SOC stocks are possible, depending on the balance between decomposition and net primary productivity (NPP) (Limpens et al. 2008, Smith \& Fang 2010). At present, there are few detailed measurements of peatland $C$ budgets both within Great Britain and globally (Billett et al. 2010). In the absence of long-term data, modelling tools are required to provide broader-scale estimates of long-term changes in $\mathrm{C}$ balances to aid policy and management decisions.

Peatland models show large differences in complexity and structure. Bioclimatic envelope models (BCEMs) range from simple statistical relationships to semiprocess-based models. They estimate the probability of blanket peat presence or absence based on persistence of a climate that is associated with peat (e.g. Clark et al. 2010, this Special, Gallego-Sala et al. 2010, this Special). It is important to note that BCEMs only tell us about changing climatic conditions, they do not model what will actually happen to the peat. Modelling of changes in soil carbon and vegetation in response to climate change is carried out by dynamic models (DMs). These range in complexity from net $\mathrm{C}$ balance models based on empirical C flux predictions (Worrall et al. 2009b) to complex dynamic process-based models that use both climatic and biogeochemical parameter data to simulate changes in peat accumulation and decomposition based on the peat cohort (i.e. organic material of similar age and depth in peat profile) (Frolking et al. 2001, Heinemeyer et al. 2010, this Special) or the size of C pool (Smith et al. 2007, Smith et al. 2010a,b, both this Special).

Both BCEMs and DMs have been used to inform policy decisions regarding blanket peat management (e.g. Smith et al. 2007, House et al. 2010). It is unclear whether simple BCEMs - that primarily predict the probability of presence or absence of a climate associated with peat-provide a closer approximation of the trajectory of change in long-term peat stability predicted by more complex DMs that calculate both the sign and the magnitude of the $\mathrm{C}$ balance.

There are advantages and disadvantages to DMs and BCEMs, such that no single model provides a fully comprehensive solution. Although DMs are appealing because they explicitly represent ecosystem processes, all such models in practice only provide a partial representation of environmental systems because of the inherent complexity of the natural environment and our incomplete understanding of these systems. For instance, most peat models (Worrall et al. 2009b, Smith et al. 2010a,b) represent the dynamics of decomposition using empirical relationships to define decomposition rates and partitioning between different gaseous 
and aquatic C fluxes. Dynamic feedbacks between water table, vegetation change and micro-topographic variations, which in turn change decomposition rates due to dynamic changes in vegetation/litter quality and hydrologic conditions, are often not included in these models, and are a recent development (Belyea \& Malmer 2004, Ise et al. 2008, Heinemeyer et al. 2010). Data to parameterise and initialise DMs are often scarce (e.g. decomposition rates, carbon pool sizes), limiting application and validation of these models (Heinemeyer et al. 2010). In addition, the detailed process representation tends to make DMs site specific and computationally expensive to run over long time periods and/or spatial scales and so may not be practical to apply at regional or global scales (Fronzek et al. 2006). By contrast, BCEMs have the advantage of only requiring readily available climatic data and can be applied quickly and easily over a wide area (e.g. Clark et al. 2010). Yet, BCEMs are based on static relationships with climate and ignore interactions between other changing variables like land use and atmospheric deposition (Hampe 2004); these limitations need to considering in any BCEM application examining climate change impacts (Heikkinen et al. 2006).

Model inter-comparison studies have highlighted how the differences in $\mathrm{C}$ cycle representation within complex models can lead to different results (e.g. Smith et al. 1997, Jones et al. 2005, Friedlingstein et al. 2006). For instance, in a comparison of 11 global climate models (GCMs), when vegetation and soil dynamics were explicitly included (coupled climate-C cycle models), all models showed an increase in atmospheric $\mathrm{CO}_{2}$ due to feedbacks from the $\mathrm{C}$ cycle (e.g. increased soil respiration and vegetation change). The magnitude of change varied considerably from +20 to +200 ppm $\mathrm{CO}_{2}$ depending on the model structure, with differences in modelled response of soil respiration to temperature being one of the major sources of variance (Friedlingstein et al. 2006). Other studies comparing changing $C$ stocks have also found agreement between models in terms of long-term decline in $\mathrm{C}$ stocks under future climate projections, although the magnitude of decline was greater from simple models with 1 SOM pool than more complex models with 5 SOM pools (Jones et al. 2005). Moreover, when compared with observational data, a comparison between 9 soil organic matter (SOM) models and long-term field observations showed that the models tested fell into 2 groups, with one group where models were developed specifically for soils and contained more SOM pools performing statistically better than the other group where models were developed for a specific system (e.g. forestry) and were not as widely tested (Smith et al. 1997).

Soil model intercomparison exercises have been useful in identifying areas for model development and observational needs (Smith et al. 1997, Randerson et al. 2009); however, these intercomparisons have mostly been carried out for mineral soils. To date, there has been little analysis of models for organic soils, in spite of their use in aiding policy and management decisions in recent years (e.g. Smith et al. 2007, Worrall et al. 2009b, House et al. 2010).

In the present study, we compare the outputs from relatively simple static BCEMs (Clark et al. 2010, Gallego-Sala et al. 2010) with more complex dynamic C accumulation and C flux models (Worrall et al. 2009b, Heinemeyer et al. 2010, Smith et al. 2010a,b) to determine whether (1) there is any agreement between complex models in terms of the change in $\mathrm{C}$ balance under more recent and future climate projections, and (2) the BECMs can give a useful indication of the probable changes. Comparison between BECMs and DMs was based on the assumption that, in areas where blanket peat is present and the BCEMs predict continued presence (due to maintaining a 'suitable' climate), the peat was assumed to be a $C$ sink (i.e. the sign of the net $\mathrm{C}$ balance is positive) whereas in areas where blanket peat was present and bioclimatic models predict blanket peat to be absent (i.e. the climate shifts away from that currently associated with peat), the peat was assumed to be a net $\mathrm{C}$ source (i.e. the sign of the $\mathrm{C}$ balance is negative).

Model comparison was carried out using data from 4 data-rich blanket peat field-sites across Great Britain where long-term monitoring data were available to parameterise and run the DMs. Two climatic data sets were used to compare model outputs over the recent observed period (1940-2005) (Perry \& Hollis 2005) and for modelled projections (1950-2099) using the Hadley Centre Regional Climate Model (HadRM3) under the A1B emissions scenario. The A1B scenario has a storyline of an integrated world with rapid economic growth and growing population until 2050 and balanced emphasis on all energy sources (Nakicenovic et al. 2000). These 11 outputs from HadRM3 (11-regional climate model [RCM] ensemble) formed part of the underlying data used to create the UKCP09 climate projections for the UK (Murphy et al. 2009).

\section{METHODS}

\subsection{Site descriptions and data availability}

Models were run for 4 blanket peat sites across Great Britain where peatland $\mathrm{C}$ balances have been monitored; 3 of these sites form part of the Centre for Ecology and Hydrology (CEH) C catchments network (www.ceh. ac.uk/sci_programmes/CarbonExchangeattheCatchment Scale.htm). A location map of each of these sites is shown 


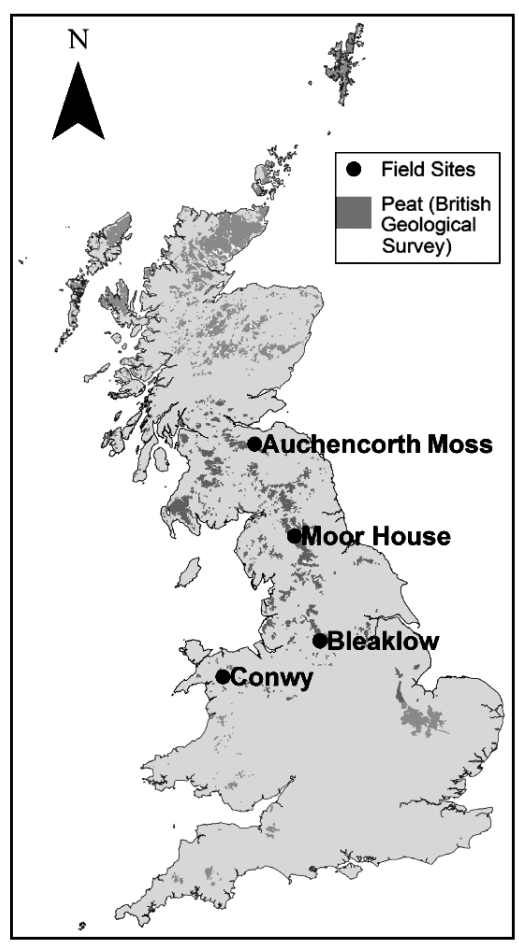

Fig. 1. Location of field sites in Great Britain with respect to peatland area. Crown copyright/database right 2009. An Ordnance Survey/EDINA supplied service. Geological Map Data NERC 2009 in Fig. 1 and brief description is given below. Sites were chosen because of the availability of parameter data, driving climatic variables and measurements of $\mathrm{C}$ fluxes and stocks needed to run and verify models (Table 2) (Billett et al. 2010).

\subsubsection{Auchencorth Moss, southern Scotland}

Auchencorth Moss is a long-term monitoring site in southern Scotland $\left(55.79^{\circ} \mathrm{N}, 3.24^{\circ} \mathrm{W}\right)$. The site is partly drained and used primarily for rough grazing, with a small amount of peat extraction to the western edge. Approximately $85 \%$ of the 335 ha is covered with blanket peat ( 0.5 to $5 \mathrm{~m}$ deep) over an altitudinal range of 248 to $300 \mathrm{~m}$ (Billett et al. 2004). Vegetation cover is dominated by Eriophorum vaginatum, Juncus effusus, and Sphagnum spp. with Calluna vulgaris in drained areas (Dinsmore \& Billett 2008). Mean annual precipitation (20022008) and temperature (1971-2000) were $1155 \mathrm{~mm}$ and $10^{\circ} \mathrm{C}$, respectively (Drewer et al. 2010). Mean water table depth at 9 dip wells was $12.5 \mathrm{~cm}$ below the surface (Dinsmore et al. 2010). Typical pH of the peat is $\mathrm{pH} 2.5$ to 3.0 in $\mathrm{CaCl}_{2}$ (Billett et al. 2004). Continuous Automatic Weather Station (AWS) data has been collected since 1995; for this work the period 2007-2008 was used. Recent measurements combining both gaseous and aquatic

Table 2. Summary of model data needs and data availability. Exact bioclimatic envelope model (BCEM) climate data requirements vary between models (Clark et al. 2010, Gallego-Sala et al. 2010, both this Special). ECOSSE is a pool-based soil organic matter model (Smith et al. 2010a,b, both this Special); MILLENNIA is a cohort-based peat accumulation model (Heinemeyer et al. 2010); and the Durham Carbon Model (DCM) is a flux-based C balance model (Worrall et al. 2009b). H: hourly, D: daily, M: monthly, A: annual, K: millennial. HOST: Hydrology of soil type (classification of soil hydrology)

\begin{tabular}{|c|c|c|c|c|c|c|c|c|}
\hline & -1 & Model data & requirements - & 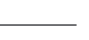 & - Field & site data avail & bility - & \\
\hline & BCEM & ECOSSE & MILLENNIA & DCM & Auchencorth Moss & Moor House & Conwy & Bleaklow \\
\hline Parameters & & & & & & & & \\
\hline Land management & & $\checkmark$ & & $\checkmark$ & $\checkmark$ & $\checkmark$ & $\checkmark$ & $\checkmark$ \\
\hline Vegetation/bare soil & & & & $\checkmark$ & $\checkmark$ & $\checkmark$ & $\checkmark$ & $\checkmark$ \\
\hline Acrotelm depth & & & & & $\checkmark$ & $\checkmark$ & $\checkmark$ & \\
\hline Bulk density & & & & & & 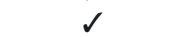 & & $\checkmark$ \\
\hline Clay content & & $\checkmark$ & & & & $\checkmark$ & & \\
\hline Carbon content & & $\checkmark$ & & & $\checkmark$ & $\checkmark$ & & $\checkmark$ \\
\hline Soil pH & & $\checkmark$ & & & $\checkmark$ & $\checkmark$ & & $\checkmark$ \\
\hline Wetness class HOST & & $\checkmark$ & & & $\checkmark$ & $\checkmark$ & $\checkmark$ & $\checkmark$ \\
\hline Hydraulic conductivity & & & & & & $\checkmark$ & & \\
\hline Basal age & & & $\checkmark$ & & & $\checkmark$ & $\checkmark$ & $\checkmark$ \\
\hline Litter quality & & & $\checkmark$ & & & $\checkmark$ & $\checkmark$ & \\
\hline Peat depth & & & & & $\checkmark$ & $\checkmark$ & & $\checkmark$ \\
\hline Decomposition rate & & & $\checkmark$ & & & $\checkmark$ & $\checkmark$ & $\checkmark$ \\
\hline Peat description & & & & & & $\checkmark$ & $\checkmark$ & $\checkmark$ \\
\hline Driving variables & & & & & & & & \\
\hline Water table & & & $\mathrm{M} / \mathrm{A}$ & $\mathrm{D} / \mathrm{M}$ & M & $\mathrm{H}$ & $\mathrm{H}$ & $\mathrm{H}$ \\
\hline Temperature & $\mathrm{M} / \mathrm{A}$ & $\mathrm{M} / \mathrm{D}$ & M/A & $\mathrm{D} / \mathrm{M}$ & $\mathrm{H}$ & $\mathrm{H}$ & $\mathrm{H}$ & $\mathrm{H}$ \\
\hline Rainfall & $\mathrm{M} / \mathrm{A}$ & $\mathrm{M} / \mathrm{D}$ & M/A & $\mathrm{D} / \mathrm{M}$ & $\mathrm{H}$ & $\mathrm{H}$ & $\mathrm{H}$ & $\mathrm{H}$ \\
\hline Rain days & & & & & $\mathrm{D}$ & $\mathrm{D}$ & $\mathrm{D}$ & $\mathrm{D}$ \\
\hline Cloudiness & $\mathrm{M} / \mathrm{A}$ & & & & & $\mathrm{D}$ & $\mathrm{D}$ & $\mathrm{H}$ \\
\hline Evaporation & $\mathrm{M} / \mathrm{A}$ & M/D & $\mathrm{M} / \mathrm{A}$ & & $\mathrm{H}$ & $\mathrm{H}$ & $\mathrm{H}$ & $\mathrm{H}$ \\
\hline Paleo climate & & & $\mathrm{K}$ & & & $\checkmark$ & & \\
\hline
\end{tabular}


carbon fluxes suggest this site is currently a net sink for C (69.5 $\left.\mathrm{g} \mathrm{C} \mathrm{m}^{-2} \mathrm{yr}^{-1}, 2007-2008\right)$ (Dinsmore et al. 2010). More details on this site can be found in Billett et al. (2004) and Dinsmore \& Billett (2008).

\subsubsection{Moor House, North Pennines}

Moor House National Nature Reserve is located in the North Pennines, England $\left(54.70^{\circ} \mathrm{N}, 2.39^{\circ} \mathrm{W}\right)$. The site has been monitored since 1992 by the Environmental Change Network (ECN). Data include continuous AWS and water table. The Cottage Hill Sike catchment is a 20 ha subcatchment of Trout Beck, covered almost entirely by blanket peat over an altitudinal range of 540 to $562 \mathrm{~m}$. Peat depth is estimated to be $2.4 \mathrm{~m}$ on average (Heinemeyer et al. 2010), although a depth range of 0.4 to $5.0 \mathrm{~m}$ has been noted across the reserve (Heal \& Smith 1978). Vegetation is dominated by Calluna vulgaris, Eriophorum vaginatum and Sphagnum spp. The typical $\mathrm{pH}$ of surface peat is $\mathrm{pH} 3.6$ to 4.3 in $\mathrm{H}_{2} \mathrm{O}$ and pH 3.0 to 3.5 in $\mathrm{CaCl}_{2}$ (Adamson et al. 2001). Mean annual rainfall is $1982 \mathrm{~mm} \mathrm{yr}^{-1}$ (19312000) and mean annual temperature is $5.3^{\circ} \mathrm{C}$ (Holden \& Adamson 2001). The water table is predominantly $5 \mathrm{~cm}$ in depth, although drawdown to $45 \mathrm{~cm}$ has been observed during drought years (Evans et al. 1999). A complete $\mathrm{C}$ budget produced for Trout Beck showed that the catchment was a small net sink of $C$, with average net $\mathrm{C}$ accumulation of $56 \mathrm{~g} \mathrm{C} \mathrm{m}^{-2} \mathrm{yr}^{-1}$ between 1993 and 2005 (Worrall et al. 2009a). More site details can be found in Adamson et al. (1998, 2001).

\subsubsection{Migneint, Conwy, North Wales}

The Migneint is located in the headwaters of the river Conwy, North Wales $\left(52.99^{\circ} \mathrm{N}, 3.80^{\circ} \mathrm{W}\right)$. Mean annual rainfall is approximately $2200 \mathrm{~mm} \mathrm{yr}^{-1}$ and mean annual temperature is $5.6^{\circ} \mathrm{C}$; mean water table elevation in an undrained part of the catchment is ca. $9 \mathrm{~cm}$. The top $15 \mathrm{~cm}$ of the peat has a $\mathrm{pH} 3.9$ in $\mathrm{H}_{2} \mathrm{O}$. Mean peat depth measured within the $1 \mathrm{~km}^{2}$ monitoring catchment is $1.2 \mathrm{~m}$ (M. Cooper pers. comm.). Vegetation is dominated by Calluna vulgaris and Eriophorum vaginatum (Ellis \& Tallis 2000). A full carbon budget for this has not yet been calculated, although long-term monitoring is underway. More site details can be found in Evans et al. (2006) and Billett et al. (2010).

\subsubsection{Bleaklow, South Pennines}

Bleaklow is located in the southern Pennines $\left(53.44^{\circ} \mathrm{N}, 1.86^{\circ} \mathrm{W}\right)$. Mean annual rainfall is $1554 \mathrm{~mm}$ $\mathrm{yr}^{-1}$ (1961-2004) (Daniels et al. 2008) and mean annual temperature is $7.1^{\circ} \mathrm{C}$. Large parts of the site have been heavily eroded, and are dissected by a number of gullies (Evans \& Lindsay 2010a). Water table drawdown is typically within the top $30 \mathrm{~cm}$ of the peat, although drawdown up to $80 \mathrm{~cm}$ has been noted close to the gully edge (Daniels et al. 2008). Peat depths range from 1 to $4 \mathrm{~m}$. Vegetation cover is principally Eriophorum vaginatum and Eriophorum augustifolium, Calluna vulgaris, Erica tetralix, Vaccinium myrtillus and Empetrum nigrum, with patches of Sphagnum spp. (Daniels et al. 2008). Since 2006, the C budget at 13 plots and 5 catchments has been monitored by Durham University and the University of Manchester. These include a range of sites from 'pristine', restored and eroded sites. Calculations based on peat growth rates (Tallis 1994) suggest that most pristine sites are a net $\mathrm{C}$ sink with a mean rate of $+20.3 \mathrm{~g} \mathrm{C} \mathrm{m}^{-2} \mathrm{yr}^{-1}$ (Evans \& Lindsay 2010b, this Special) with other estimates varying between +70 to $+102 \mathrm{~g} \mathrm{C} \mathrm{m}^{-2} \mathrm{yr}^{-1}$ (Billett et al. 2010). The sites are described in more detail in Daniels et al. (2008).

\subsection{Models}

Static statistical and semi-process-based BCEMs and process-based DMs were used, each with differing structure and data requirements, are described below and in Table 2 .

\subsubsection{BCEMs (P50, P65, LM, H-GLM, BBOG, BBOG- TREE, BBOG-GLM, BBOG-GAM, PEATSTASH)}

The 9 BCEMs used average climate data for precipitation, temperature and cloudiness to predict the presence or absence of blanket peat (Clark et al. 2010, Gallego-Sala et al. 2010). Four models were published previously: P50 is a simple threshold model (i.e. where blanket peat presence is predicted when the chosen climate variable is above or below defined values) based on annual precipitation where blanket peat is found in areas with annual precipitation $>1250 \mathrm{~mm}$ $\mathrm{yr}^{-1}$ (Pearsall 1950); P65 is also a simple threshold model where peat is found in areas where the annual potential evaporation (PE) is less than a third of annual precipitation (Pearsall 1965); LM is another simple threshold model where blanket peat is found in areas where total annual precipitation is $>1000 \mathrm{~mm} \mathrm{yr}^{-1}$ and mean temperature of the warmest month is $<15^{\circ} \mathrm{C}$ (Lindsay 1995); and H-GLM which is a logistic regression model based on average temperature (Hossell et al. 2000). Four models were derived by Clark et al. (2010) from further statistical analysis: BBOG is a 
threshold-based model based on the sum of the annual accumulated monthly water deficit (AAMWD; i.e. precipitation - PE); BBOG-TREE is a regression tree model using maximum temperature, the ThornthwaiteMather moisture index (TMI) and AAMWD; BBOGGLM is a logistic regression model using maximum temperature and the TMI; BBOG-GAM is a generalised additive model based on minimum temperature, continentality (difference between maximum and minimum temperature) and the TMI. One model, PEATSTASH, was derived from a semi-process-based global bioclimatic model (Sykes et al. 1996) that defines blanket peat presence or absence based on maximum temperature and a derived moisture index (Gallego-Sala et al. 2010). The BCEMs are described in more detail in Clark et al. (2010) and Gallego-Sala et al. (2010).

The BECMs were originally calibrated to the current mapped blanket peat area using average climate data for 1961-1990 (Clark et al. 2010, Gallego-Sala et al. 2010). The data were averaged over a $30 \mathrm{yr}$ period to factor out interannual variability. For the model analysis described in this paper, the BECMs were also run using 30 yr mean monthly climate data to be consistent with the input data used to calibrate the models.

\subsubsection{Multi-pool dynamic simulation model (ECOSSE)}

The ECOSSE model (Estimating Carbon in Organic Soils Sequestration and Emission) calculates the net $\mathrm{C}$ storage within soils by calculating the net decay of each of the conceptual SOM pools (Smith et al. 2007, 2010a,b) after an initial short-term soil C spin-up period using average climate and water table information as well as SOC stock data. The spin-up process runs the model using an assumed plant input until the rate of change of SOC matches the observed value. The plant inputs are then adjusted according to the ratio of simulated to measured SOC and the simulation is repeated until both the simulated SOC and the rate of change of SOC match the measured values. This approach is consistent with the majority of SOC models (Smith 2001). The SOM pools are rapidly decomposing organic matter, slow turnover organic matter and inert organic matter. Inputs to the system are as resistant plant material and decomposable plant material. Carbon cycling is based upon the Rothamsted Carbon (RothC) model, developed for mineral soils (Coleman \& Jenkinson 1996), although ECOSSE has been developed to also simulate anaerobic processes in organic soils (Smith et al. 2007, 2010a).

Decomposition within each pool is described by first order kinetics where decompositions is dependent on the amount of material within that pool, and the decomposition rates are modified to account for changes in temperature, moisture, $\mathrm{pH}$ and land management. Monthly climatic data were used to drive the model. Water table was used as a static input parameter rather than being simulated. Plant inputs were estimated using the spin up to match initial measured soil $\mathrm{C}$ as described in Smith et al. (2010a). During the dynamic phase of the simulation, plant inputs were further adjusted according to climate using the Miami model (Leith \& Box 1972), where NPP is calculated based on empirical relationships with mean annual temperature and total precipitation.

ECOSSE calculates both the changes in the size of all $\mathrm{C}$ pools over time (i.e. changes in overall $\mathrm{C}$ stock) and the fluxes of $\mathrm{C}$ in gaseous and aquatic form. In both cases, the overall net $\mathrm{C}$ balance can be calculated from either the net change in the $\mathrm{C}$ stock or the balance between inputs and simulated fluxes. Output data were provided on a monthly time step and were aggregated to 1, 10 and $30 \mathrm{yr}$ periods for comparison with other model outputs.

\subsubsection{Peat accumulation model (MILLENNIA)}

MILLENNIA (i.e. considering millennia of peat accumulation and therefore no short-term equilibrium SOC spin up) uses either constant or variable past annual mean climate data over the entire period of peat development (i.e. in the UK context this is estimated to be approximately 10000 yr by Heinemeyer et al. (2010). The net $\mathrm{C}$ storage within the peat is estimated by modelling the net $\mathrm{C}$ balance within each soil layer or cohort (as opposed to pools), either accumulating or decomposing peat based on the balance between NPP and overall decomposition based on litter quality defined decomposition rates. NPP is calculated empirically after Leith \& Box (1972), where the mass of dry matter (converted to $\mathrm{C}$, assuming $50 \%$ of dry matter is $\mathrm{C}$ ) is estimated from site actual evapotranspiration (AET). Litter decomposition rates are based on the initial litter quality fraction specific decay rates (i.e. lignin, holocellulose and soluble), which are then subject to internal (i.e. ligono-cellulose quotient and nitrogen-factor) and external (i.e. soil temperature, water table and oxygen availability) factors that modify the decomposition rate. The model considers 8 plant functional types (PFTs; Sphagnum, other bryophytes, herbs, shrubs, trees, grasses, sedges and rushes) differing in litter quality and root NPP C inputs. The NPP input of the PFTs is allowed to change over time, reflecting water table changes based on a simple hydrological model. First, the model was run annually for an initial $10000 \mathrm{yr}$ peat accumulation period (i.e. to grow peat depth corresponding to time since peat initiation) using a recreated past climate, then monthly climate data were used 
as available to drive the model, calculating a dynamic water table with respect to the balance between precipitation, evapotranspiration and runoff.

Like ECOSSE, MILLENNIA then calculates both annual changes in overall $\mathrm{C}$ stock over time and the balance between inputs and $\mathrm{C}$ fluxes via gaseous $\left[\mathrm{CO}_{2}\right.$ and methane $\left.\left(\mathrm{CH}_{4}\right)\right]$ and aquatic (total organic carbon in runoff) fluxes (Heinemeyer et al. 2010). Output data were provided on an annual time step and were aggregated to 1,10 and $30 \mathrm{yr}$ periods for comparison with other model outputs.

\subsubsection{Dynamic flux model (Durham Carbon Model)}

The Durham Carbon Model calculates the net carbon balance by calculating the main flux pathways: input via gross primary production (GPP) and output via gaseous $\left(\mathrm{CO}_{2}\right.$ and $\left.\mathrm{CH}_{4}\right)$ and aquatic fluxes (dissolved $\mathrm{CO}_{2}$, DOC and particulate organic carbon [POC]) (Worrall et al. 2009b). All flux estimates were based on empirical relationships between precipitation and/or water table elevation. Water table fluctuations within the model are determined from the balance between precipitation and evapotranspiration from the peat profile developed for the Moor House catchment (Worrall \& Burt 2005). Monthly climate data averaged over a 10 yr period were used to drive the model.

The Durham Carbon Model was initially developed to understand the impact of management (e.g. burning, grazing, land drainage, etc.) on peat $\mathrm{C}$ fluxes over medium-term (i.e. $10 \mathrm{yr}$ ) time periods. It estimates the net $\mathrm{C}$ balance only, from the balance between GPP and C fluxes, and does not report changes in the $\mathrm{C}$ stock. Output data were provided as an average annual value over a $10 \mathrm{yr}$ period, and were aggregated in to $30 \mathrm{yr}$ periods for comparison.

\subsection{Climate data}

\subsubsection{Observed data (Met Office/UKCP)}

To provide a long-term, consistent climate data set for each field site, time series for key climatic variables (Table 2) were extracted for each location from the Met Office/UKCP $5 \mathrm{~km}$ gridded data sets (www.metoffice. gov.uk). The gridded data were produced by integrating long-term meteorological measurements using interpolation and multiple regression models based on location (easting and northing), terrain elevation, open water and urban land use (Perry \& Hollis 2005). Total monthly precipitation, maximum and minimum temperature, and sunshine hours from 1940 to 2005 were used. Gridded data from 2006 onwards were not avail- able. Mean daily temperature was determined as the average of maximum and minimum temperature (Allen et al. 1998). Sunshine hours were converted to percentage cloud cover for daylight hours. The converted daylight cloud cover data (1940-2005) were then corrected relative to the measured cloud cover data (1961-2000) by applying a factorial change determined from the period where the 2 data sets overlapped.

\subsubsection{Projected data (11-member RCM data ensemble)}

Monthly transient modelled and projected climate data (1950-2100) were obtained from the 11-member RCM ensemble (HadRM3-PPE-UK) and run for the A1B (medium) emissions scenario only. Data were obtained from the British Atmospheric Data Centre (BADC; http://badc.nerc.ac.uk/home/index.html). Daily precipitation, maximum and minimum temperature and cloud cover were extracted for each $25 \mathrm{~km}$ grid cell overlying each field site and then aggregated to monthly values.

\subsubsection{Correction of output statistics from Met Office/UKCP and 11-member RCM data}

Measured meteorological data for Moor House and Conwy for periods that overlapped with the Met Office/UKCP gridded climate data (i.e. 2005 and earlier) were used to correct for biases in the monthly precipitation and temperature data due to long-term systematic differences between these data series. Factorial changes (i.e. percentage multiplier) were determined from the gridded data and observed data for precipitation and cloud cover changes, whereas differences (i.e. fixed values) in the temperature data were identified. For Auchencorth Moss and Bleaklow, measured meteorological data for the period 2007 and 2008 were used. Therefore, correction of the gridded data was performed relative to the corrected modelled 11-member RCM data (described below) for the period 1991-2005 using the same method used for Moor House and Conwy.

The 11-member RCM ensemble data were also corrected using similar factorial and difference methods for monthly precipitation and temperature data to account for systematic deviations between measured and modelled data series (correction of model output statistics [MOS]; Maraun et al. 2010). MOS correction factors/ differences were determined using the mean value for the 11-member RCM output rather than each individual model run, as this maintained the variation in output between each of the ensemble members. For Moor House and Conwy, correction factors/differences were 
determined between the corrected gridded data and 11member RCM mean between 1991 and 2005. As noted above, for Bleaklow and Auchencorth Moss, correction was determined between the observed data and the 11member RCM mean as observed data did not overlap with the gridded data set. Comparison between the long-term averages for 1961-1989 for the Met Office/UKCP and 11-member RCM ensemble mean showed that the MOS correction was effective at adjusting both data sets to represent a similar magnitude of temperature and precipitation conditions at each of the field sites studied (Table 3).

\subsubsection{Potential evaporation calculations}

PE was estimated using the Priestley-Taylor model (Priestley \& Taylor 1972). To determine whether the choice of PE model significantly affected simulations, model outputs for Moor House were compared with 2 other PE models: Hargreaves (Hargreaves et al. 1985, Allen et al. 1998) and Thornthwaite (Thornthwaite 1948). These methods were chosen as they had minimal data requirements (temperature and cloud cover) which were available from the long-term data. Extraterrestrial and net radiation were estimated using
Julian day and the latitude of each site following methods outlined in Allen et al. (1998). More physically based models like Penman-Monteith require additional data, such as wind speed, that are often unavailable. For climate change studies, previous work has shown that temperature-based evaporation equations provide more reliable estimates of potential evaporation from GCM model output data as there is less uncertainty with temperature than other climatic variables like wind speed (Kay \& Davies 2008).

\subsection{Model comparison and data analysis}

The model comparison procedure followed a similar principle to the method outlined in Smith et al. (1997). The aim of the comparison was to determine whether models were able to provide broadly consistent measures of peat stability and not to compare the detailed short-term processes represented. Hence, DM outputs compared were the magnitude of the net $\mathrm{C}$ balance ( $\mathrm{g} \mathrm{C} \mathrm{m}^{-2} \mathrm{yr}^{-1}$ ), the sign of the net $\mathrm{C}$ balance ( 1 for positive and 0 for negative) and changes in overall $\mathrm{C}$ stock $\left(\mathrm{kg} \mathrm{C} \mathrm{m}{ }^{-2}\right)$. Relevant climate and parameter data were made available to the modellers, who were then asked to use their own judgement to calibrate and para-

Table 3. Summary climate data. Correction of monthly gridded 5 km Met Office/UKCP gridded data (1940-2005) and 25 km 11-member regional climate model (RCM) ensemble data (1950-2099), and projected future climate change from the 11-member RCM ensemble. Annual mean values for the 11-member RCM ensemble are shown, with the range from minimum to maximum change shown in brackets. Rain and cloud clover cover corrections were applied as factorial changes and temperature changes were applied as differences to monthly data. AC: Auchencorth Moss; BK: Bleaklow; CW: Conwy; MH: Moor House. Note that for

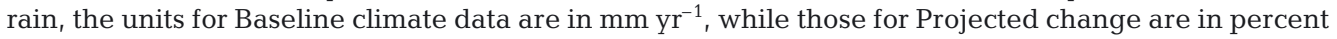

\begin{tabular}{|c|c|c|c|c|c|c|}
\hline \multirow[t]{2}{*}{ Site } & \multicolumn{4}{|c|}{ Baseline climate 1960-1989 } & \multicolumn{2}{|c|}{- Projected climate change -} \\
\hline & Grid (raw) & Grid (corr.) & RCM (raw) & RCM (corr.) & RCM (corr.) 2040-2069 & RCM (corr.) 2070-2099 \\
\hline \multicolumn{7}{|c|}{ Rain $\left(\mathrm{mm} \mathrm{yr}^{-1}\right)$} \\
\hline $\mathrm{AC}$ & 1023 & 1046 & 726 & 998 & $+3.7 \%(-8.1$ to $+13.2 \%)$ & $+4.2 \%(-5.4$ to $+13.3 \%)$ \\
\hline MH & 1283 & 1683 & 1523 & 1784 & $+0.3 \%(-15.4$ to $+19.8 \%)$ & $+0.9 \%(-13.9$ to $+22.4 \%)$ \\
\hline BK & 1128 & 1359 & 1130 & 1303 & $+1.5 \%(-12.2$ to $+17.4 \%)$ & $+1.5 \%(-11.8$ to $+17.3 \%)$ \\
\hline $\mathrm{CW}$ & 2565 & 2136 & 1742 & 2172 & $+2.1 \%(-13.5$ to $+20.9 \%)$ & $+1.8 \%(-14.1$ to $+23.9 \%)$ \\
\hline \multicolumn{7}{|c|}{ Max. temperature $\left({ }^{\circ} \mathrm{C}\right)$} \\
\hline $\mathrm{AC}$ & 10.3 & 10.3 & 10.7 & 10.4 & $+2.6(+1.6$ to +3.2$)$ & $+3.7(+2.4$ to +4.8$)$ \\
\hline $\mathrm{MH}$ & 6.78 & 7.89 & 8.97 & 8.03 & $+2.6(+1.6$ to +3.3$)$ & $+3.8(+2.7$ to +4.9$)$ \\
\hline BK & 10.58 & 8.14 & 11.00 & 8.66 & $+2.7(+1.7$ to +3.4$)$ & $+3.9(+2.8$ to +5.0$)$ \\
\hline $\mathrm{CW}$ & 9.61 & 9.16 & 9.61 & 9.37 & $+2.6(+1.6$ to +3.2$)$ & $+3.7(+2.7$ to +4.7$)$ \\
\hline \multicolumn{7}{|c|}{ Min. temperature $\left({ }^{\circ} \mathrm{C}\right)$} \\
\hline $\mathrm{AC}$ & 3.40 & 3.11 & 4.18 & 3.16 & $+2.5(+1.3$ to +3.1$)$ & $+3.5(+2.1$ to +4.5$)$ \\
\hline $\mathrm{MH}$ & 1.85 & 2.23 & 3.36 & 2.28 & $+2.5(+1.3$ to +3.2$)$ & $+3.5(+2.1$ to +4.6$)$ \\
\hline BK & 4.59 & 3.34 & 4.45 & 3.44 & $+2.5(+1.4$ to +3.1$)$ & $+3.6(+2.2$ to 4.6$)$ \\
\hline CW & 4.10 & 3.08 & 3.93 & 3.26 & $+2.4(+1.3$ to +3.2$)$ & $+3.5(+2.1$ to +4.5$)$ \\
\hline \multicolumn{7}{|c|}{ Cloud cover (\%) } \\
\hline $\mathrm{AC}$ & 72.3 & - & 60.8 & 72.9 & $-2.8(-10.7$ to +8.0$)$ & $-2.0(-8.0$ to +8.7$)$ \\
\hline $\mathrm{MH}$ & 72.1 & - & 70.4 & 71.2 & $-3.0(-15.4$ to +19.8$)$ & $+0.8(-13.9$ to +22.4$)$ \\
\hline $\mathrm{BK}$ & 70.1 & - & 63.4 & 70.3 & $-4.7(-11.1$ to +1.7$)$ & $-3.4(-8.9$ to +3.0$)$ \\
\hline $\mathrm{CW}$ & 71.8 & - & 71.3 & 70.9 & $-3.3(-2.7$ to +7.7$)$ & $-4.8(-9.7$ to +1.8$)$ \\
\hline
\end{tabular}


meterise their models and to provide as many of the outputs requested as possible. All models (DMs and BCEMs) were able to produce a binary output indicating net $\mathrm{C}$ balance over a 30-yr period; only 2 DMs (ECOSSE and MILLENNIA) could produce data for both net $\mathrm{C}$ balance and overall change in $\mathrm{C}$ stock.

As noted above, BCEMs do not explicitly calculate the $\mathrm{C}$ balance, they only predict the probability of presence or absence of blanket peat at a particular location based on the presence or absence of a climate currently associated with peat presence (Clark et al. 2010, Gallego-Sala et al. 2010). To compare the outputs of the BCEMs with DMs, a number of assumptions need to be made about the implications of change in the prediction of blanket peat presence or absence for peat accumulation and, therefore, net $\mathrm{C}$ balance and $\mathrm{C}$ source/sink status. If the mapped blanket peat area can be assumed to represent areas of active peat formation or areas where peat can be sustained, the calibrated BCEMs can also be assumed to show areas of active and sustained peat growth where there is a net accumulation (or no net loss) of $\mathrm{C}$, indicating the peat is a $\mathrm{C}$ sink. If climate projections show a change in the bioclimatic space such that blanket peat is predicted to become absent from an area over time, this suggests that peat accumulation will no longer occur as the climate becomes unfavourable to support blanket peatlands. Under unfavourable climatic conditions for peat formation or sustainability, we assume that there will be a net loss of $\mathrm{C}$, such that areas become a net $\mathrm{C}$ source.

The exact $95 \%$ confidence intervals were calculated using the Student's $t$-distribution. Data analysis was carried out in Excel and R (version 2.7) (R Development Core Team 2008).

\section{RESULTS}

\subsection{Trends in the observed and projected climate data}

It is important to understand the underlying trends in climate data as this will influence the DM and BCEM predictions. All 4 sites are characterised by a cool and wet climate with mean monthly minimum temperatures of 2.2 to $3.3^{\circ} \mathrm{C}$, mean monthly maximum temperatures of 7.9 to $10.3^{\circ} \mathrm{C}$ and mean annual precipitation of 1046 to $2136 \mathrm{~mm} \mathrm{yr}^{-1}$ from the corrected Met Office/ UKCP gridded climate data for the baseline period (1960-1989) (Table 3). The corrected data provided similar results to published long-term average climate; however, some differences between the data presented in Table 3 and data quoted above (see Section 2) are likely to be due to differences in the time periods covered.
The coolest to warmest sites are in the order Moor House < Conwy < Auchencorth Moss < Bleaklow in terms of minimum temperature and Moor House < Bleaklow < Conwy < Auchencorth Moss in terms of maximum temperature for 1960-1989. Wettest to driest sites are in the order Conwy $>$ Moor House $>$ Bleaklow $>$ Auchencorth Moss for the same period. Cloud cover is similar between sites, ranging from 70.1 to $72.3 \%$ on average for the period 1960-1989 (Table 2), with considerable interannual variability $\quad<60$ to $>85 \%$; Fig. 2).

Total annual precipitation was highly variable between years in both observed and modelled data for both recent observations and future projections (Fig. 2 ). There was little apparent long-term trend in mean total annual precipitation from 1950-2099, with only a small increase averaged across all 11-member RCM models $(+0.9$ to $+4.2 \%$ of $1960-1989$ by $2070-2099$; Table 3), with large variability between the outputs of different models $(-14.1$ to $23.9 \%$ of $1960-1989$ by 2070-2099; Table 3). It is important to note that longterm trends in the balance between summer and winter precipitation have been reported, and both UKCIP02 and UKCP09 projections suggest that these trends will continue over this century (Hulme et al. 2002, Murphy et al. 2009). Projections for cloud cover show a slight decrease over time, although like precipitation, there was considerable variability between each model output with individual model runs showing both an increase or decrease in cloud cover (-13.9 to $22.4 \%$ for 1960-1989 by 2070-2099; Table 3). By contrast, both projections for maximum and minimum temperature show a steady increase of +2.6 to $2.7^{\circ} \mathrm{C}$ on average by $2040-2069$ and +3.7 to $3.9^{\circ} \mathrm{C}$ on average by 2070-2099 (Table 3). Therefore, temperature showed the strongest long-term trend, followed by cloud cover; as temperature and cloud cover also influence PE estimates, changes in these variables could affect responses driven directly by temperature and indirectly by the net water balance.

\subsection{Influence of climate data on model outputs}

\subsubsection{Influence of PE model}

The Priestley-Taylor model for PE was primarily used for this study. To determine whether the choice of PE model influenced the output of the 2 DMs, MILLENNIA and ECOSSE, that used PE as a driving variable, differences in the net C balance from 1940 to 1999 for Moor House determined using the Priestley-Taylor model were compared with estimates made using the Hargreaves and Thornthwaite models (Fig. 3). As the choice of PE models was explicit in the BCEMs, 


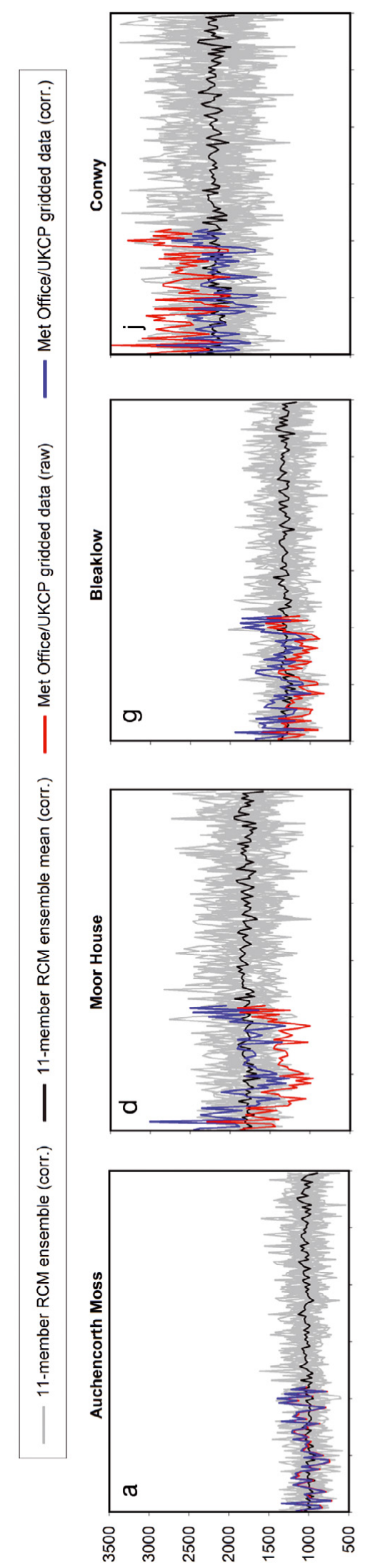

Total precipitation $\left(\mathrm{mm} \mathrm{yr}^{-1}\right)$
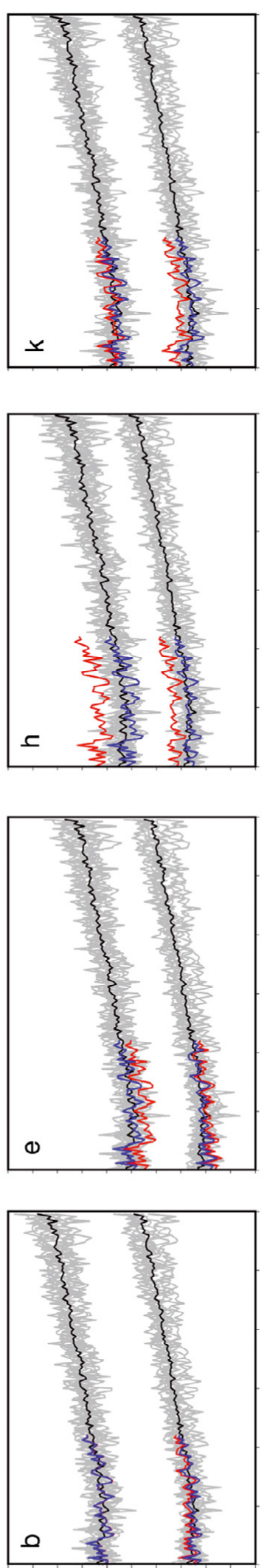

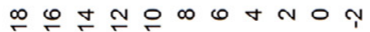

Temperature $\left({ }^{\circ} \mathrm{C}\right)$

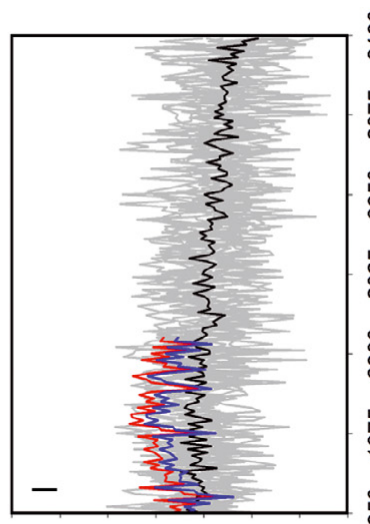

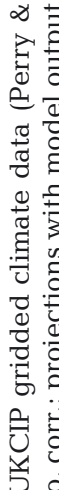

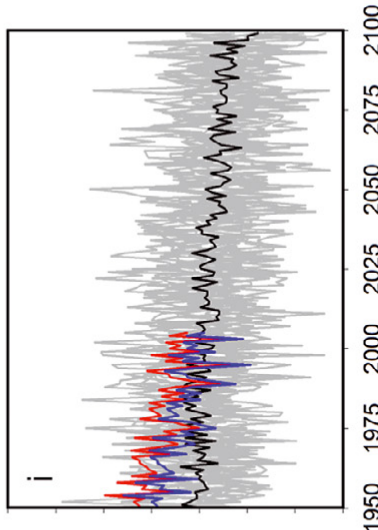

Ð

总总

एँ है

. n

䒕 थ

흥 데 제

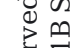

远

ठ욜.

宊

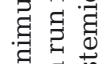

表要悹

웅

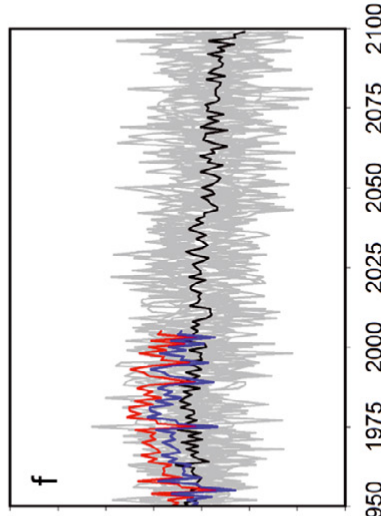

\%

可

灵

刍证

要递

过

胥

品

류

元

营

인

ปี

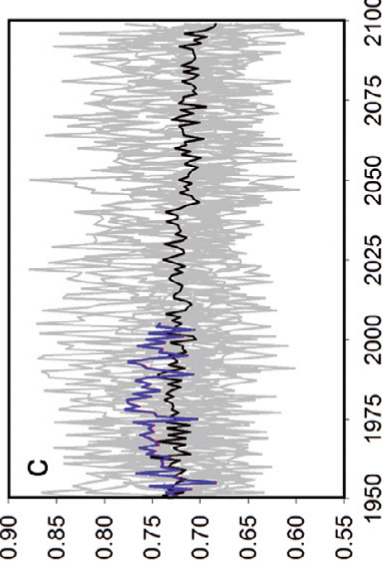

จ

常

홍

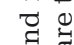

ชิ $\frac{\pi}{\pi}$

$2 \pi$

剀

.

일

릅

舒㝵 


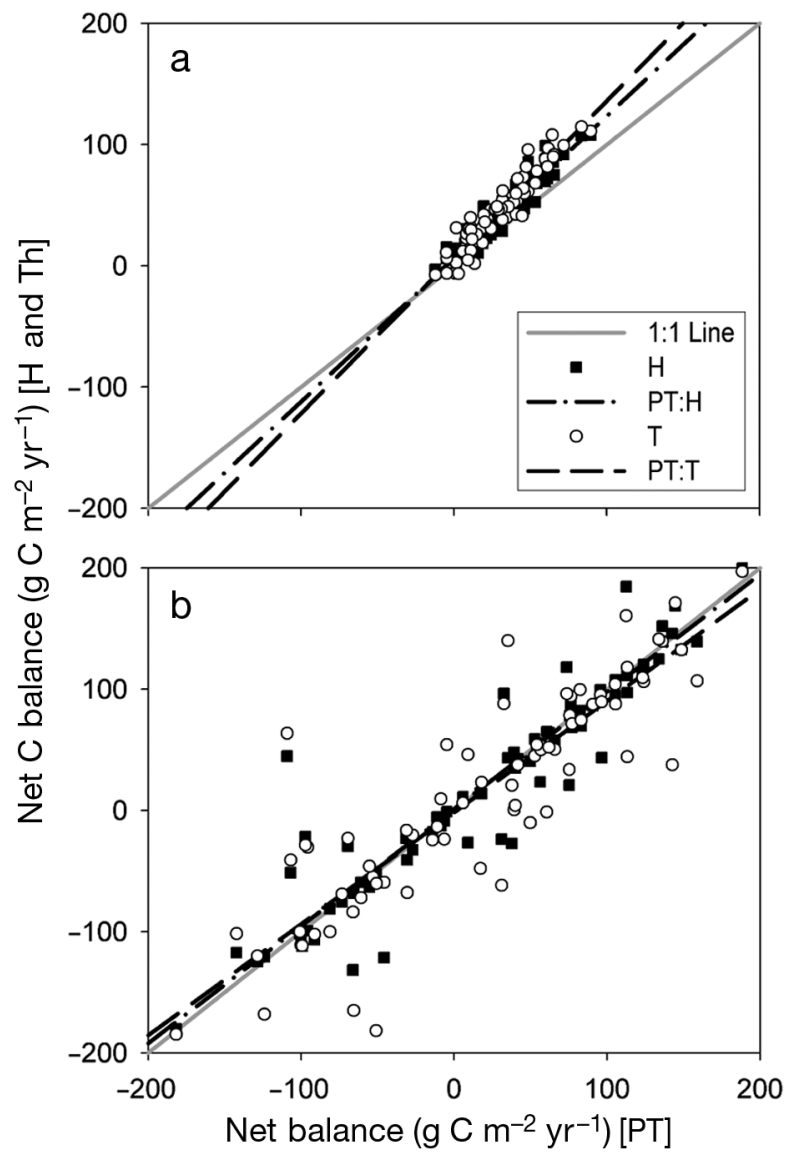

Fig. 3. Relationships between annual net C balance (19401999) calculated using different potential evaporation models for (a) MILLENNIA and (b) ECOSSE. Potential evaporation models used were Priestley-Taylor (PT; Priestley \& Taylor 1972), Hargreaves $\left(H_{i}\right.$ Hargreaves 1985) and Thornthwaite (Th, Thornthwaite \& Mather 1955)

Table 4. Variation in potential evaporation (PE) and net $\mathrm{C}$ balance calculated using raw Met Office/UKCP data for Moor House using different PE models (1940-1999). Data are averaged over $10 \mathrm{yr}$

\begin{tabular}{|c|c|c|c|}
\hline \multirow[t]{2}{*}{$\mathrm{V}$} & \multicolumn{3}{|c|}{ - PE model } \\
\hline & Priestley-Taylor & Hargreaves & Thornthwaite \\
\hline \multicolumn{4}{|c|}{ PE $\left(\min \mathrm{yr}^{-1}\right)$} \\
\hline Mean & 379 & 461 & 486 \\
\hline SD (10 yr) & 4 & 21 & 10 \\
\hline $\mathrm{SD}(1 \mathrm{yr})$ & 12 & 29 & 18 \\
\hline \multicolumn{4}{|c|}{ Net $\mathrm{C}$ balance $\left(\mathrm{g} \mathrm{m}^{-2} \mathrm{yr}^{-1}\right)$} \\
\hline Mean & 26.9 & 35.3 & 41.0 \\
\hline SD (10 yr) & 8.3 & 12.4 & 10.5 \\
\hline $\mathrm{SD}(1 \mathrm{yr})$ & 20.7 & 24.4 & 28.1 \\
\hline \multicolumn{4}{|l|}{ ECOSSE } \\
\hline Mean & 8.6 & 7.6 & 7.5 \\
\hline SD (10 yr) & 16.1 & 17.8 & 11.8 \\
\hline $\mathrm{SD}(1 \mathrm{yr})$ & 88.6 & 90.5 & 91.2 \\
\hline
\end{tabular}

Table 5. Mean net $\mathrm{C}$ balance $\left(\mathrm{g} \mathrm{C} \mathrm{m}^{-2} \mathrm{yr}^{-1}\right)$ over the baseline climate period (1960-1989) between raw and corrected Met Office/UKCP data. Data are mean and $95 \%$ confidence interval, based on the data averaged over $10 \mathrm{yr}$ period

\begin{tabular}{|lcc|}
\hline & \multicolumn{2}{c|}{ Net C balance- } \\
\cline { 2 - 3 } & Raw & Bias-corrected \\
\hline Auchencorth Moss & & \\
MILLENNIA & $30.5 \pm 0.7$ & $29.6 \pm 0.7$ \\
ECOSSE & $15.6 \pm 13.5$ & $22.5 \pm 37.7$ \\
Durham & $136.5 \pm 1.6$ & $137.0 \pm 5.7$ \\
Moor House & & \\
MILLENNIA & $21.8 \pm 0.5$ & $7.7 \pm 0.2$ \\
ECOSSE & $3.5 \pm 39.0$ & $3.4 \pm 64.7$ \\
Durham & $147.5 \pm 1.2$ & $141.8 \pm 1.1$ \\
Bleaklow & & \\
MILLENNIA & $32.7 \pm 0.8$ & $29.1 \pm 0.7$ \\
ECOSSE & $7.6 \pm 45.7$ & $10.0 \pm 59.7$ \\
Durham & $130.1 \pm 0.4$ & $137.3 \pm 6.9$ \\
Conwy & & \\
MILLENNIA & $-2.7 \pm 0.1$ & $12.1 \pm 0.2$ \\
ECOSSE & $-11.3 \pm 61.1$ & $4.2 \pm 238.4$ \\
Durham & $127.3 \pm 5.0$ & $133.9 \pm 0.2$ \\
\hline
\end{tabular}

the influence of the different PE models was not compared here. In general, the Priestley-Taylor model provided lower PE estimates (mean of $379 \mathrm{~mm} \mathrm{yr}^{-1}$ ) than both Hargreaves and Thornthwaite (mean of 461 and $486 \mathrm{~mm} \mathrm{yr}^{-1}$, respectively), using the raw Met Office/ UKCP data (Table 4). The net $\mathrm{C}$ balance by MILLENNIA increased with PE estimated by the different models and showed a very small decrease from ECOSSE estimates (Table 4). This implies that MILLENNIA is more sensitive to changes in PE than ECOSSE, and that the models differ in their response to changes in $\mathrm{PE}$. Given the model structure, the small decrease in net $\mathrm{C}$ balance predicted by ECOSSE is due to a small increase in decomposition under drier conditions. By contrast, the increase in net $\mathrm{C}$ balance predicted by MILLENNIA is due to increased NPP and changes in PFT groups associated with the dynamic water table.

\subsubsection{Influence of correction of Met Office/UKCP data on dynamic and statistical model results}

The Met Office/UKCP and 11-member RCM ensemble data were both corrected to account for systematic differences between the modelled and observed data for each site. Comparison between the model predictions for the raw and corrected Met Office/UKCP data shows that corrections influenced the magnitude and sometimes sign of the net $\mathrm{C}$ balance (Table 5). Specifically, MOS correction altered the estimated net $\mathrm{C}$ balance for Moor House and Conwy for MILLENNIA and for all sites except Moor House for ECOSSE, but had less impact on the Durham Carbon Model (Table 5). 
The implications are that MILLENNIA and ECOSSE are more sensitive to differences in input climate data than the Durham Carbon Model, although their actual sensitivity and response to climate variables differs (see Section 3.2.1.).

For the BCEMs, MOS correction had the greatest influence on predictions for Bleaklow, and to a lesser extent Auchencorth Moss, where correction increased the number of BCEMs predicting blanket peat presence (Fig. 4). For both sites, the same BCEMs predicted blanket peat absence: P50 and P65. Both these BCEMs were based on thresholds of either total precipitation or the ratio between total precipitation and PE (Pearsall 1950, 1965, Clark et al. 2010) (Tables S1 and S2 in the Supplement, available at www.intres.com/articles/suppl/c045p227_supp.pdf).

\subsection{Estimated blanket peat $\mathrm{C}$ budget and probability of blanket peat presence from observed climate data (1940-1999)}

\subsubsection{Relationship between DMs}

For the observed historic period, the Durham Carbon Model predicted the greatest C sink, with the least variation between sites. ECOSSE showed the lowest net $\mathrm{C}$ balance (i.e. the smallest sink) with a net C source at Conway (Table 5, Fig. 5). ECOSSE was also the most sensitive model to climate drivers, showing the greatest interannual variability (Fig. 5). Although MILLENNIA showed less interannual variability than ECOSSE and generally estimated a greater net $\mathrm{C}$ sink, model outputs between MILLENNIA and ECOSSE were more similar to each other than to the Durham Carbon Model (Fig. 5). When averaged over a $30 \mathrm{yr}$ period (Fig. 5), models generally showed a decline in the net $\mathrm{C}$ balance (i.e. less $\mathrm{C}$ taken up or more C emitted) from 1940-1969 to 1970-1999. Specifically, MILLENNIA predicted a decline for all sites (-20 to $-61 \%)$ and ECOSSE predicted a decline for all sites ( -30 to $-125 \%$ ) except Auchencorth Moss, where the net $\mathrm{C}$ sink increased $(+178 \%)$ because of increased plant inputs over the period. The Durham Carbon Model predicted a small decline for Bleaklow and Conwy (-0.6 and $-0.5 \%$, respectively) and a small increase for Moor House and Auchencorth Moss (0.1 and $0.4 \%$, respectively). MILLENNIA and ECOSSE both predicted that Conwy and Moor House were closer to the threshold between net $\mathrm{C}$ sink or source than Auchencorth Moss and Bleaklow, whereas the Durham Carbon Model predicted little difference between sites with a net $\mathrm{C}$ sink an order of magnitude greater than the other models (>100 g C m${ }^{-2} \mathrm{yr}^{-1}$; Table 5).

\subsubsection{Relationship between modelled and measured estimates of net $\mathrm{C}$ balance}

Modelled estimates of net $\mathrm{C}$ balance were compared with measured estimates of net $\mathrm{C}$ balance for Auchencorth Moss and Moor House, as these sites were the only locations where data were available before 2005 (the year when Met Office/UKCP data ends). For Auchencorth Moss, year-on-year estimates of the average net $\mathrm{C}$ balance vary from $-8.3 \mathrm{~g} \mathrm{C} \mathrm{m}^{-2} \mathrm{yr}^{-1}$ for the period 1996-1998 (Billett et al. 2004) to $+69.5 \mathrm{~g} \mathrm{C} \mathrm{m}^{-2}$ $\mathrm{yr}^{-1}$ for the period 2007-2008 (Dinsmore et al. 2010). These values reflect significant interannual variability, which are largely caused by differences in net ecosystem exchange. Over an extended period, however, the site would appear to be acting as a $\mathrm{C}$ sink; this is consistent with the model predictions (Table 6). In addition, both the 1996-1998 and 2007-2008 measured estimates were within the range of values estimated by both ECOSSE and MILLENNIA but were an order of magnitude lower than the Durham Carbon Model predicted. Moor House has a longer record of monitoring data, with an estimated net $\mathrm{C}$ balance of $56 \mathrm{~g} \mathrm{C} \mathrm{m}^{-2}$ $\mathrm{yr}^{-1}$ between 1993 and 2005 (Worrall et al. 2009a). This value is greater than the long-term average $C$ sink predicted by ECOSSE and MILLENNIA. Furthermore, other net C balance estimates based on longer-term C peat accumulation rates indicate values of approximately $25 \mathrm{~g} \mathrm{C} \mathrm{m}^{-2} \mathrm{yr}^{-1}$ (Garnett 1998), very close to the ECOSSE and MILLENNIA predictions (Tables 6 \& 7). Although comparison between measured and modelled data shows some discrepancies and variability between years, values predicted by ECOSSE and MILLENNIA are a similar order of magnitude and within a realistic range of plausible values.

Table 6. Comparison between measured and modelled net $\mathrm{C}$ balance $\left(\mathrm{g} \mathrm{C} \mathrm{m}^{-2} \mathrm{yr}^{-1}\right.$ ) (range in parentheses) using corrected Met Office/UKIP gridded data for years where measured data are available before 2005. Measured $\mathrm{C}$ balance has been determined from previous flux measurements (Billett et al. 2004, Worrall et al. 2009a, Billett et al. 2010, this Special, Dinsmore et al. 2010). A negative sign indicates a net source of $C$ from the peat and a positive sign indicates a net sink of $\mathrm{C}$ to the peat

\begin{tabular}{|c|c|c|}
\hline & \multicolumn{2}{|c|}{ Net $\mathrm{C}$ balance -} \\
\hline & $\begin{array}{l}\text { Auchencorth Moss } \\
\text { (1996-1998) }\end{array}$ & $\begin{array}{l}\text { Moor House } \\
(1993-2005)\end{array}$ \\
\hline Measured & -8.3 & $+56(+20$ to +90$)$ \\
\hline \multicolumn{3}{|l|}{ Modelled } \\
\hline MILLENNIA & $+33.5(-1.3$ to +56.1$)$ & $+17.2(-22.0$ to +125$)$ \\
\hline ECOSSE & $+19.0(-97.0$ to +82.5$)$ & $+18.7(-22.0$ to +125$)$ \\
\hline Durham & $+134^{\mathrm{a}}$ & +77 \\
\hline \multicolumn{3}{|c|}{$\begin{array}{l}{ }^{a} \text { Outputs from the Durham Carbon Model are averaged } \\
\text { over the period 1990-1999 }\end{array}$} \\
\hline
\end{tabular}


Table 7. Net C balance ( $\mathrm{g} \mathrm{C} \mathrm{m}^{-2} \mathrm{yr}^{-1}$ ) predicted by the dynamic models between 1960-1989, 2040-2069 and 2070-2099 using the corrected 11-member RCM ensemble data

\begin{tabular}{|c|c|c|c|c|c|c|c|}
\hline \multirow[t]{2}{*}{ Field site } & \multirow[t]{2}{*}{ Model } & \multicolumn{2}{|c|}{$-1960-1989 \_$} & \multicolumn{2}{|c|}{$-2040-2069-$} & \multicolumn{2}{|c|}{$-2070-2099$} \\
\hline & & Mean & Range & Mean & Range & Mean & Range \\
\hline \multirow[t]{3}{*}{ Auchencorth Moss } & MILLENNIA & 31.6 & $24.6-36.3$ & 31.0 & $26.3-35.7$ & 32.5 & $27.2-37.3$ \\
\hline & ECOSSE & 19.8 & $13.0-35.3$ & 12.1 & $-1.99-26.9$ & -0.26 & $-10-13.4$ \\
\hline & Durham & 88.4 & $86.6-90.4$ & 81.3 & $75.7-86.0$ & 76.4 & $71.2-83.0$ \\
\hline \multirow[t]{3}{*}{ Moor House } & MILLENNIA & 27.4 & $5.8-38.3$ & 31.3 & $15.8-37.5$ & 34.5 & $13.3-39.4$ \\
\hline & ECOSSE & 32.2 & $18.0-60.0$ & -11.7 & $-26.7-13.8$ & -24.1 & $-44.1--4.3$ \\
\hline & Durham & 84.2 & $82.0-89.5$ & 77.8 & $73.6-85.4$ & 72.1 & $68.8-82.2$ \\
\hline \multirow[t]{3}{*}{ Bleaklow } & MILLENNIA & 36.5 & $28.7-41.9$ & 35.8 & $30.5-40.6$ & 38.4 & $29.1-45.6$ \\
\hline & ECOSSE & 21.3 & $13.9-33.6$ & 8.3 & $0.2-25.5$ & -2.8 & $-12.9-6.8$ \\
\hline & Durham & 85.6 & $83.0-90.4$ & 78.3 & $75.1-84.0$ & 72.3 & $69.3-80.6$ \\
\hline \multirow[t]{3}{*}{ Conwy } & MILLENNIA & 22.1 & $8.5-42.5$ & 26.9 & $17.7-44.6$ & 29.6 & $21.4-42.3$ \\
\hline & ECOSSE & 15.4 & $-14.1-56.7$ & -52.0 & $-120.5-12.9$ & -79.2 & $-131.4-39.9$ \\
\hline & Durham & 78.4 & $45.0-85.4$ & 67.2 & $-0.1-81.6$ & 58.6 & $-42.5-77.4$ \\
\hline
\end{tabular}

\subsubsection{Relationship between dynamic and statistical models}

For the historical period, the semi-process-based BCEM PEATSTASH provided similar predictions to the statistical BCEMs (Fig. 4), consistent with findings at the national scale (Gallego-Sala et al. 2010). Although most DMs predicted sites to be a net $\mathrm{C}$ sink and most BCEMs predicted blanket peat presence, the DMs and BCEMs differed in terms of sites which appeared to be closer to the net $\mathrm{C}$ source/sink or blanket peat presence/absence threshold. BCEMs suggested that Auchencorth Moss and Bleaklow were more vulnerable in terms of a potential shift from presence to absence (Fig. 4), whereas the DMs suggested that Moor House and Conwy were closer to shift from net $\mathrm{C}$ sink to source (Fig. 5).

\subsection{Estimated blanket peat $\mathrm{C}$ budget and probability of blanket peat presence from predicted future climate data (1950-2099)}

\subsubsection{Relationship between net $\mathrm{C}$ balance estimated from Met Office data and from the 11-member RCM ensemble data for baseline period (1960-1989)}

Differences exist between the net $\mathrm{C}$ balance predicted by the 3 DMs from the different climate data sources over the baseline period 1960-1989 (Tables 5 \& 7). The mean net $\mathrm{C}$ balance for both MILLENNIA and ECOSSE for the corrected Met Office/UKCP data (Table 5) is within the range of values predicted using the 11-member RCM ensemble data for the same time period (Table 7). By contrast, the net $\mathrm{C}$ balance for the Durham Carbon Model for the corrected Met Office data (Table 5) were greater than the range of values estimated from the 11-member RCM ensemble (Table 7). As with the Met Office/UKCP data, the mean values for the 11-member RCM climate data for ECOSSE and MILLENNIA were more similar to each other than to the Durham Carbon Model. During this period, all models estimate all sites to be a net $\mathrm{C}$ sink, with the exception of Conwy, which ECOSSE predicted to be either a net sink or source across the 11member RCM climate projections.

\subsubsection{Long-term trends in net $\mathrm{C}$ balance and $\mathrm{C}$ sink strength predicted by DMs}

In general, ECOSSE predicted a decrease in the net $\mathrm{C}$ balance over time at all 4 sites with a corresponding shift from net $\mathrm{C}$ sink to source; the Durham Carbon Model predicted a general decrease in net $\mathrm{C}$ sink although all sites remain a net $\mathrm{C}$ sink (except Conwy); and, in contrast, MILLENNIA predicted a gradual and sometimes small increase in net $C$ sink (Table 7 , Fig. 6). ECOSSE showed the greatest variation in magnitude and sign of the net $\mathrm{C}$ balance, with the greatest variability between each model run seen at Conwy, followed by Moor House, and the least variability at Bleaklow (Fig. 6).

The variability between each of the 11-member RCM model runs and trends in the predicted net $\mathrm{C}$ balance for ECOSSE and MILLENNIA were also seen in the $\mathrm{C}$ 'sink strength' (i.e. where the magnitude of change in the $\mathrm{C}$ flux is compared with the size of the $\mathrm{C}$ pool within the model) (Fig. 7). However, only Conwy and some predicted output from Moor House showed a reduction in net $\mathrm{C}$ storage to values less than the initial values in 1950. Although the rate of $\mathrm{C}$ sequestration 


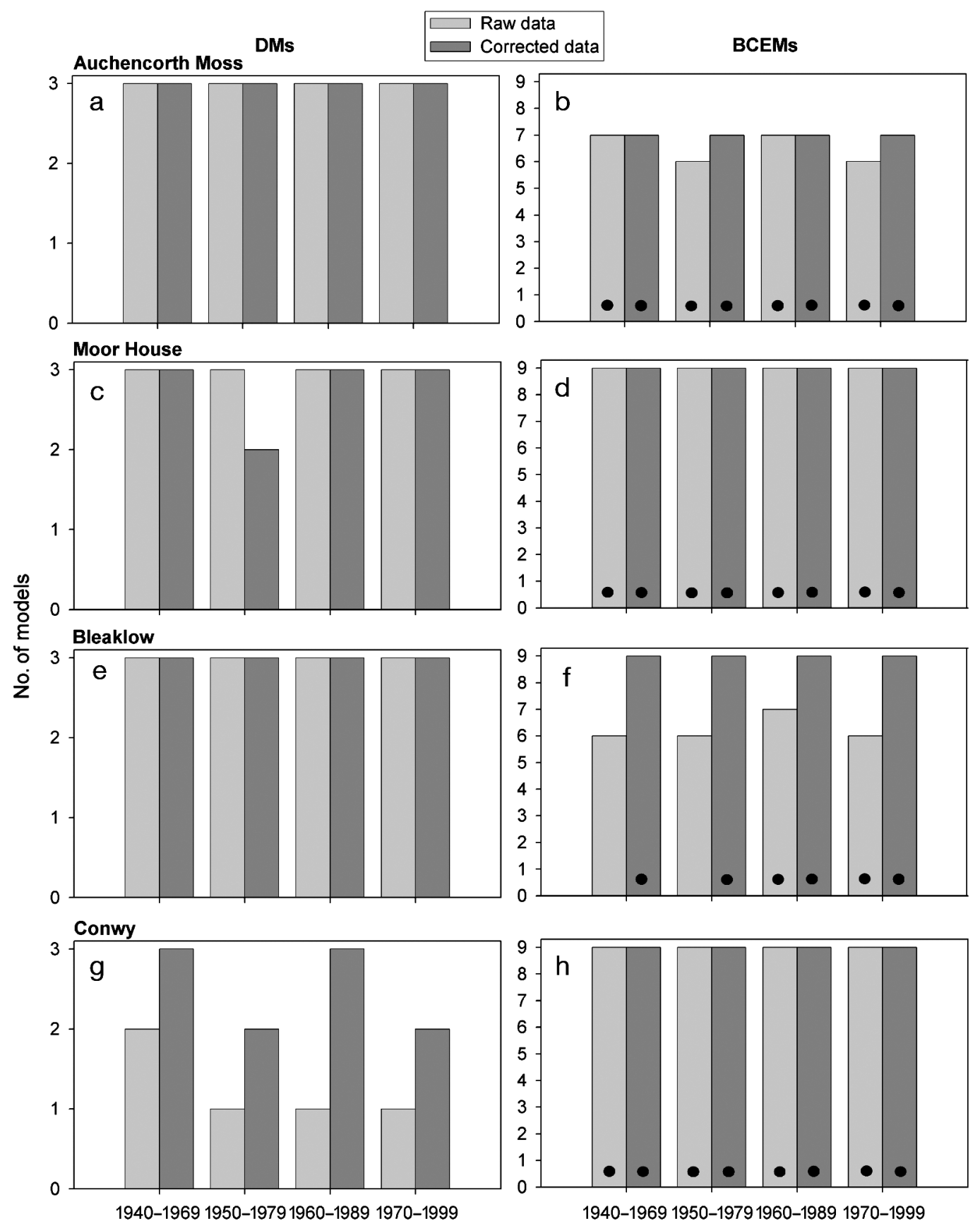

Fig. 4. Number of dynamic models (DMs) predicting a net C sink and number of bioclimatic envelope models (BCEMs) predicting climate associated with blanket peat presence for the raw and corrected Met Office/UKCIP gridded data. Black circles indicate years where PEATSTASH predicts probability of blanket peat presence

declined at both Bleaklow and Auchencorth Moss, the sink strength in both cases was $>1$, and so ECOSSE still predicted an overall net increase in the peatland $\mathrm{C}$ sink over the 150 yr period at these sites (Fig. 7). In contrast to the other 2 models, MILLENNIA showed a steady increase in sink strength over this time period, in response to the gradual increase in net $\mathrm{C}$ balance (Table 7).

\subsubsection{Relationship between dynamic and statistical models under future climate projections}

When considered together, the DM outputs show a decline in the number of models predicting a net $\mathrm{C}$ sink towards the end of this century, with a minimum of 1-2 out of the 3 models predicting a net $\mathrm{C}$ sink by 2070-2099 (Fig. 8). The shift from net C sink to source 

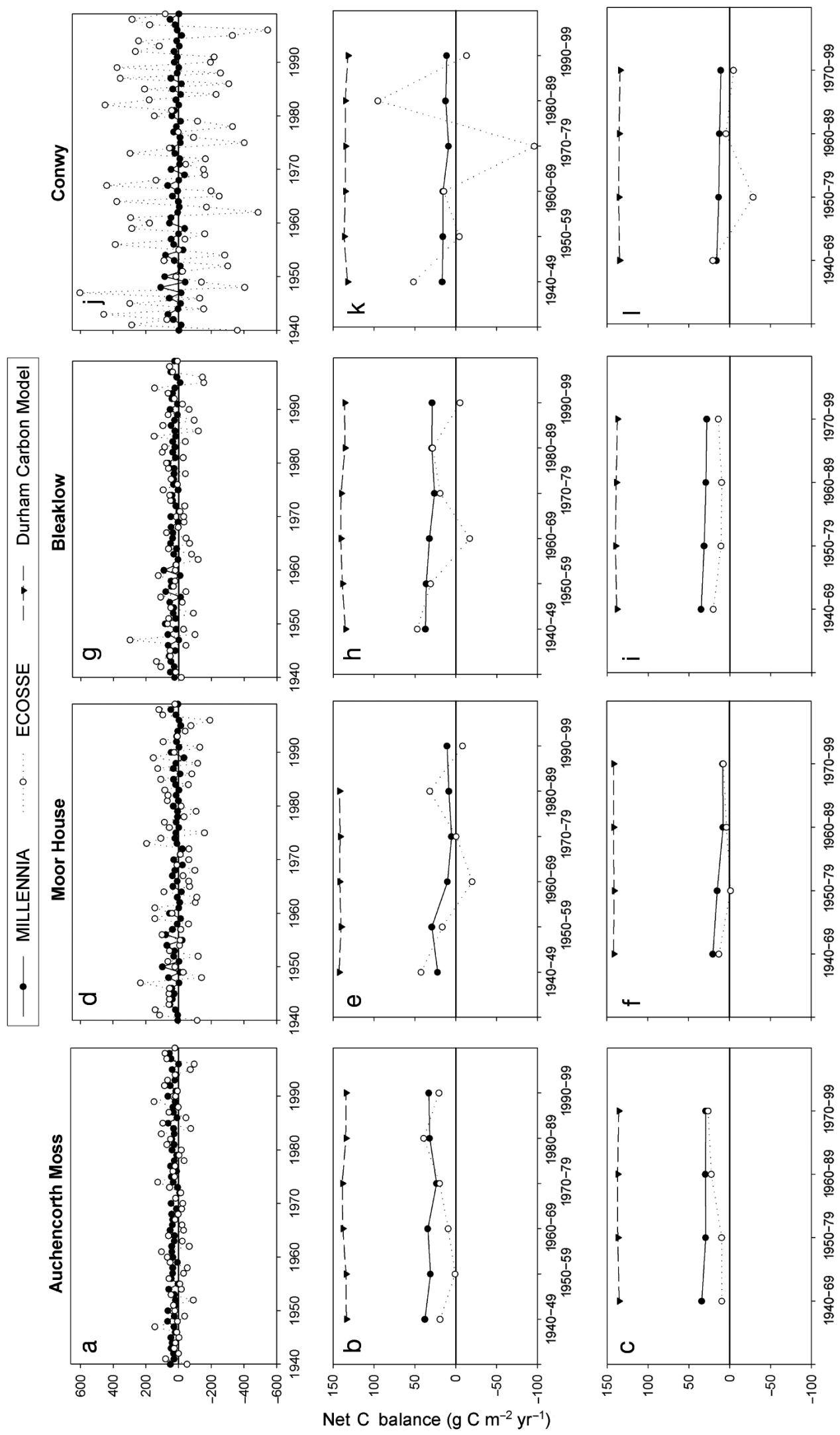

Fig. 5. Magnitude of the net annual $\mathrm{C}$ balance predicted by each of the dynamic models and averaged over 1,10 and 30 yr periods using corrected gridded Met Office/UKCP data. NB: 1 yr outputs for Durham Carbon Model were not available 

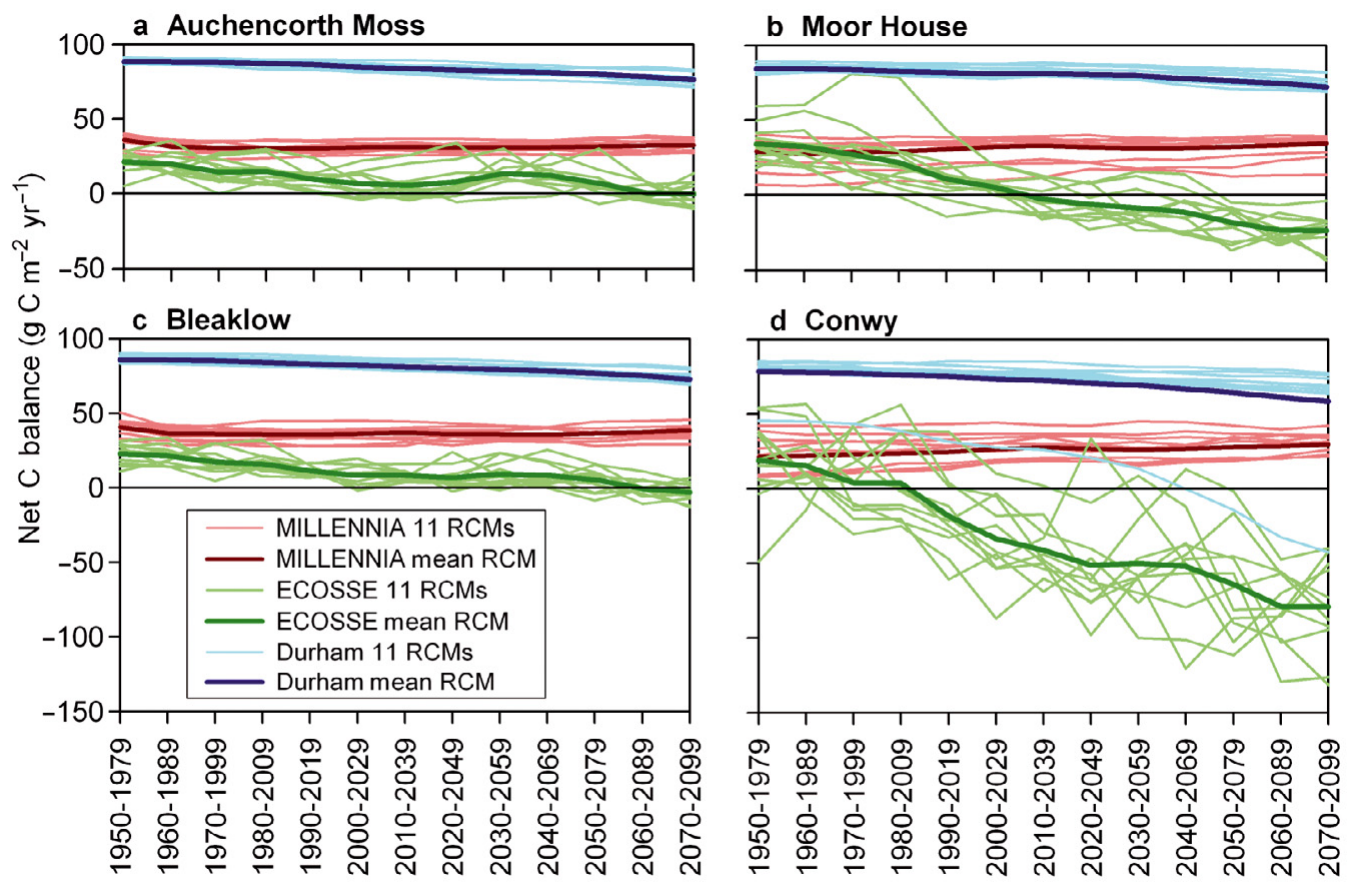

Fig. 6. Long-term trends in the net annual $\mathrm{C}$ balance predicted by the dynamic models, averaged over 30 yr periods between 1950 and 2099 using the corrected projections from the 11-member RCM ensemble data
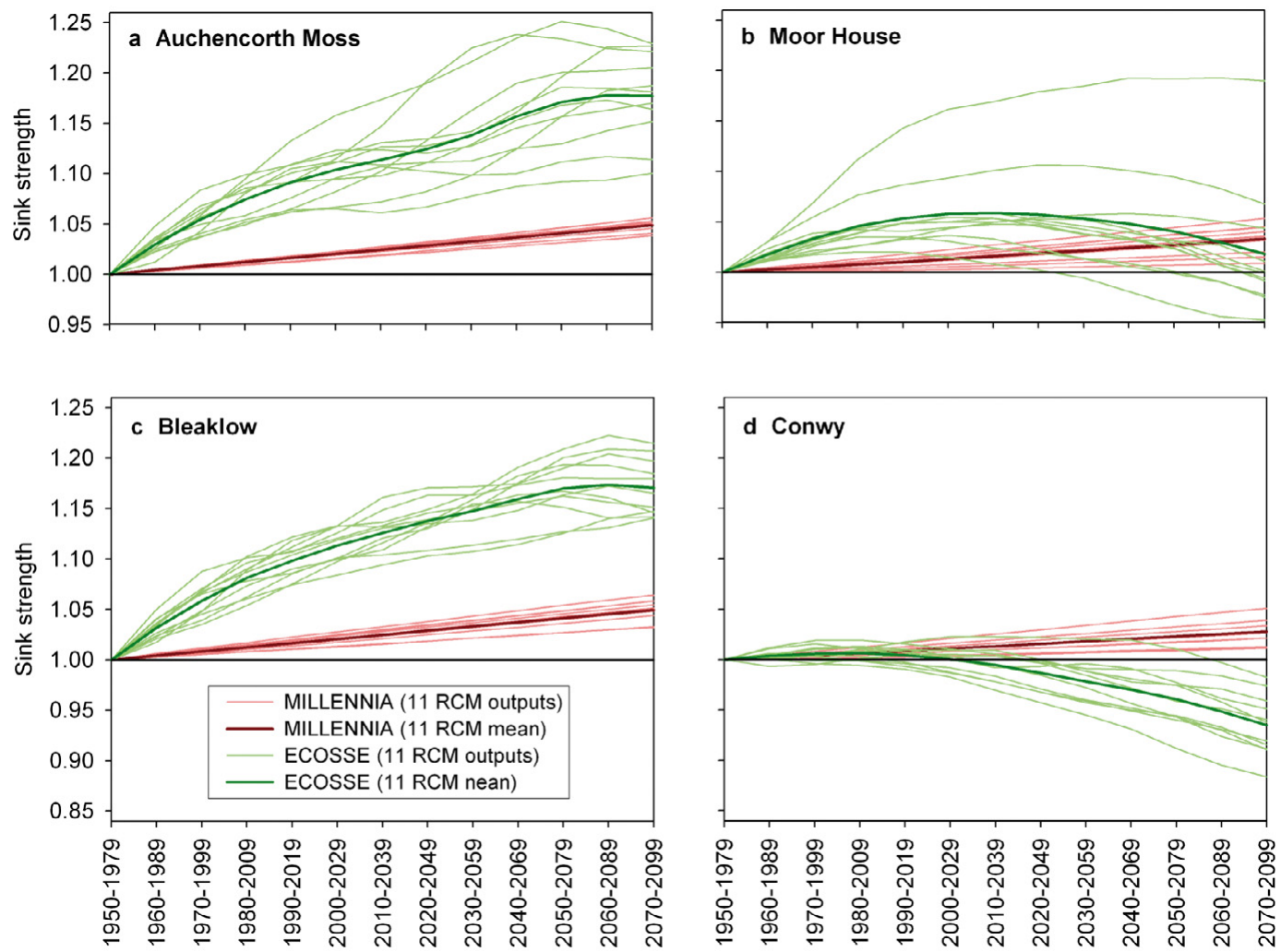

Fig. 7. Change in the net $\mathrm{C}$ sink strength over 30 yr periods for MILLENNIA and ECOSSE. Sink strength was calculated as the ratio between C stock during 1950-1979 and future time periods. Increasing sink strength shows a net C accumulation relative to 1950-1979 and decreasing sink strength shows net C depletion relative to 1950-1979. The Durham Carbon Model was not included as changes in total C stocks were not reported by this model 

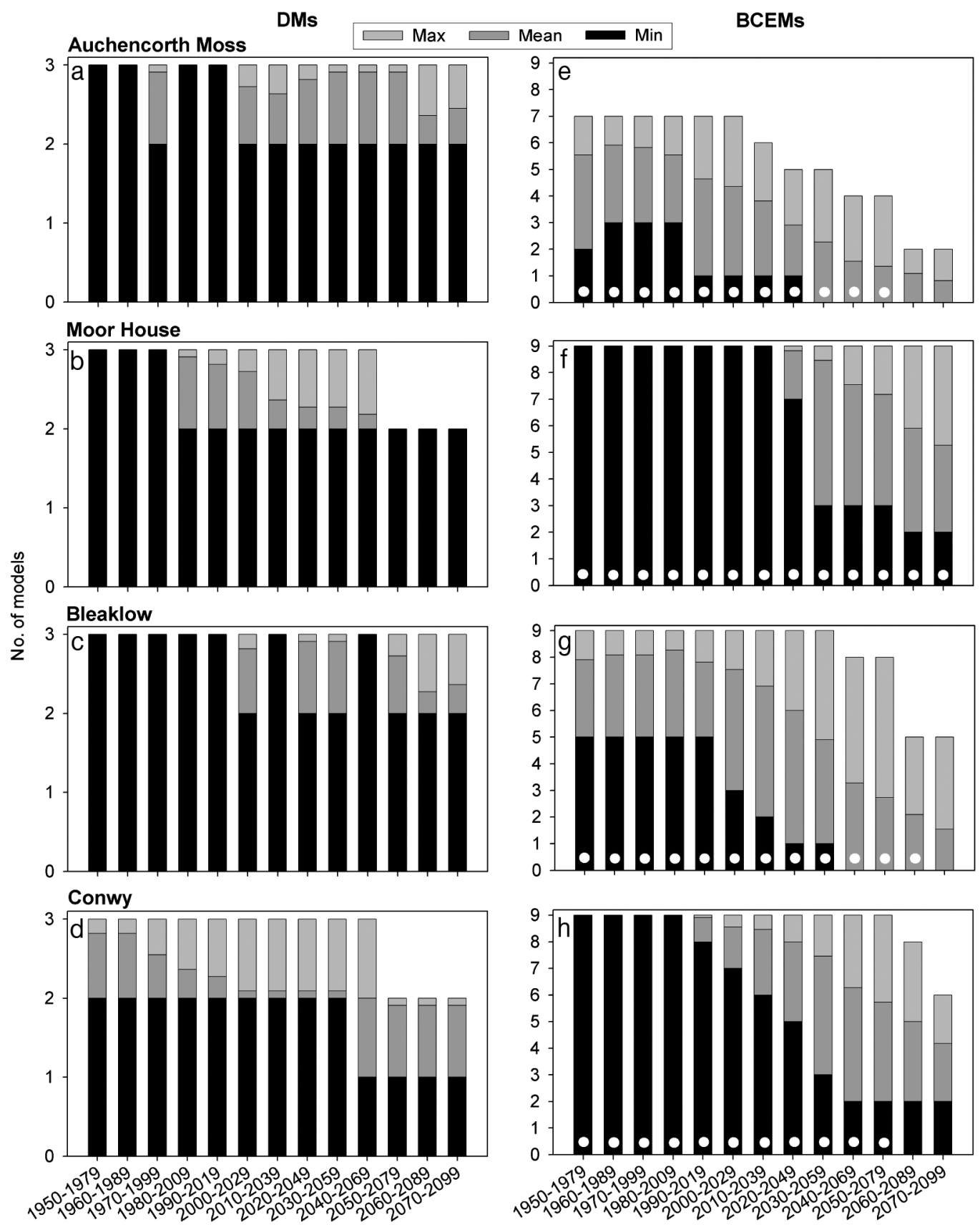

30 yr period

Fig. 8. Number of dynamic models predicting a net $\mathrm{C}$ sink and number of bioclimatic envelope models predicting climate associated with blanket peat presence for the corrected 11-member RCM ensemble data. Minimum, mean and maximum outputs for the 11 different simulations are shown. White circles show years where PEATSTASH predicts blanket peat presence in at least 1 of the 11 RCM climate projections

was mainly predicted by ECOSSE and the Durham Carbon Model in one instance for Conwy (Fig. 6, Table S3). As noted before (Fig. 4), the DMs predict Conwy and Moor House to be the most vulnerable blanket peat sites in terms of a reduction or reversal of the $\mathrm{C}$ sink by the end of this century (Figs. 6 \& 8). Like the DMs, the BCEMs (including PEATSTASH) also show the potential for increased vulnerability of blanket peat under projected future climate change, as the climate space associated with blanket peat presence declines over time with a minimum of 0-2 BCEMs covering the sites by 2070-2099 (Table S3 in the supplement at www.int-res.com/articles/ suppl/c045p227_supp.pdf). 


\section{DISCUSSION}

The DMs estimate all sites to be a net C sink during the baseline period (1960-1989) from the corrected Met Office/UKCP data. The size of the current $C$ sink estimated by ECOSSE and MILLENNIA (+3.4 to +29.6 g C $\mathrm{m}^{-2} \mathrm{yr}^{-1}$ across all sites for 1960-1989; Table 5), is close to the 'typical' long-term net accumulation rate of northern peatlands of approximately $20 \mathrm{~g} \mathrm{C} \mathrm{m}^{-2} \mathrm{yr}^{-1}$ (Gorham 1991, Vitt et al. 2000). By contrast, the Durham Carbon Model predicted a significantly greater net C sink (133.9 to $141.8 \mathrm{~g} \mathrm{C} \mathrm{m}^{-2} \mathrm{yr}^{-1}$ across all sites for 1960-1989; Table 5), with less variation between sites and years than predicted by the other DMs. Compared with measured $\mathrm{C}$ fluxes over shorter time periods at 2 of the actual sites studied, Auchencorth Moss and Moor House (Table 6), the observed results were within the range of those modelled by ECOSSE and MILLENNIA; however, these ranges were quite large and varied from sink to source. There were considerable differences between the modelled climate output of the 11member RCM ensemble, particularly with regard to precipitation, and this is partly why the range in the modelled C flux is so large. Furthermore, there were significant differences in the way models represent interannual variability and responses to key climatic drivers. Interannual variation in net $\mathrm{C}$ accumulation is characteristically large in peatlands, in spite of steady longer-term rates of $\mathrm{C}$ accumulation (Belyea \& Clymo 2001). For instance, at Auchencorth Moss the measured net $C$ balance varied from net $C$ source $\left(-8.3 \mathrm{~g} \mathrm{C} \mathrm{m}^{-2}\right.$ $\mathrm{yr}^{-1}$ for 1996-1998; Billett et al. 2004) to net $\mathrm{C}$ sink (+69.5 $\mathrm{g} \mathrm{C} \mathrm{m}^{-2} \mathrm{yr}^{-1}$ for 2007-2008; Dinsmore et al. 2010) over ca. 10 yr. Therefore, to some extent, these models may be realistic in capturing the magnitude of interannual variation. It is encouraging that ECOSSE and MILLENNIA reproduce reasonable estimates for the longterm net $\mathrm{C}$ balance over $30 \mathrm{yr}$ periods.

Differences between DM increases under future climate can be explained by differences in model structure. ECOSSE predicted an overall decline in magnitude of the net $C$ balance, with many sites shifting from net sink to source, whereas MILLENNIA predicted an increase in net $\mathrm{C}$ sink at all sites over time. The Durham Carbon Model showed the least variability over time and between sites. Decomposition rates in all models responds to changes in temperature and water table; however, the sensitivity to these changes differed inherently between models. MILLENNIA appeared to be more sensitive to changes in water balance (specifically PE) whereas ECOSSE and the Durham Carbon Model appeared more sensitive to changes in temperature. Therefore, the declining trend in net $\mathrm{C}$ balance under future climate projections predicted by ECOSSE and the Durham Carbon Model is likely to be due to increased decomposition rates relative to the increase in plant productivity under warmer temperatures. By contrast, the overall slight increase in net $\mathrm{C}$ balance predicted by MILLENNIA is likely due to this model being the only one to also consider dynamic feedbacks between water table, PFT and associated changes in litter quality. These cause a negative rather than a positive feedback on decomposition, whilst temperature increased NPP through increased AET, therefore resulting in an overall increase in net $\mathrm{C}$ accumulation. A full assessment of DM sensitivity is needed to verify this relationship.

For the baseline period, the BCEMs predicted blanket peat presence consistent with DM predictions of a net $\mathrm{C}$ sink. As the BCEMs were calibrated relative to the baseline period (Clark et al. 2010, Gallego-Sala et al. 2010), this is unsurprising. As temperature and $\mathrm{PE}$ increased under future climate projections, BCEMs consistently predicted increased absence of a climate associated with blanket peat presence. The trend for a shift from predictions of blanket peat presence to absence was broadly consistent with the pattern of predictions for shift from net $\mathrm{C}$ sink to source by ECOSSE, although the timing and rate of change differed between models. In particular, BCEMs predicted the drier sites with the lowest total annual precipitation (Auchencorth Moss and Bleaklow) to be closer to the presence/absence threshold, whereas ECOSSE predicted the cooler and wetter sites (Moor House and Conwy) to be closer to the threshold between net $\mathrm{C}$ sink/source. The Durham Carbon Model predicted sites to remain a net $\mathrm{C}$ sink, although the trajectory of change (i.e. decline in net $\mathrm{C}$ sink) was consistent with the BCEM trends. As MILLENNIA predicted an overall slight increase in the future net $C$ sink at all sites, these projections were inconsistent with the trajectory for change predicted by the BCEMs.

As BCEMs were calibrated to the existing blanket peat map, assuming all these peatlands are areas of active peat formation, they could be adjusted in future to bring predictions of blanket peat presence/absence in line with areas of net $\mathrm{C}$ accumulation based on either an improved national map based on field measurements or a national map based on modelled estimates of the net $\mathrm{C}$ balance produced by models like ECOSSE. However, further work would be required to examine how robust recalibrated models were in terms of predicting response to projected changes in climate. Previous model inter-comparisons between static BCEMs and process-based DMs for tree species in boreal and temperate regions found that BCEMs tended to predict stronger extinction and greater expansion/colonization than process-based DMs because more localised feedbacks and processes were not included (Morin \& Thuiller 2009). 
Every model is a simplification and incomplete representation of the system, and it does not necessarily follow that the most complex models are the most accurate (Smith et al. 1997). It is commonly impossible to identify the 'best' or most 'representative' model for all situations. The results here indicate that BCEMs, in some situations, can provide a broadly consistent indication of change that is also predicted by some DMs. However, there may be a more fundamental reason for differences between BCEMs and DMs. It is plausible that the climatic conditions needed for peat initiation are not the same as those that allow peat to grow once a peatland is established. Therefore, models defining the bioclimatic space where peat occurs do not necessarily capture the same climatic variables that control the dynamics between primary production and decomposition. If this is the case, then future model development may need to integrate both BCEMs and DMs in order to effectively define the geographic location for peat formation and associated accumulation rate. A similar principle is already used in global dynamic vegetation models (Prentice et al. 2007), which apply bioclimatic constraints on the potential presence of a PFT in addition to physiological calculations that determine that plant type's rates of assimilation, respiration and growth wherever it is present.

Perhaps the greatest variation in response was not between the structurally different BCEMs and DMs, but between the DMs themselves. The discrepancy between DMs is large and has very different implications in terms of a positive or negative feedback to the climate system. Other studies have predicted either a net $\mathrm{C}$ source because of increased decomposition (e.g. Jones et al. 2005) or a net C sink because of increased NPP relative to decomposition (e.g. Qian et al. 2010). Quantifying and modelling the balance between changes in NPP and decomposition under a changing climate is poorly understood and a key research priority (Smith \& Fang 2010).

Future development of C cycling models in blanket peat will need to address key uncertainties including the availability of parameter data and the conceptual representation of processes in models. It is well known that peatland plant species, vegetation productivity, peat decomposition and $\mathrm{C}$ fluxes are influenced by water table elevation (Moore et al. 1998, Freeman et al. 2001b, Strack et al. 2006, Clark et al. 2009). However, models do not always include a dynamic representation of water table and the associated changes in vegetation type and micro-topography (Belyea \& Clymo 2001, Belyea \& Malmer 2004, Heinemeyer et al. 2010). These dynamic feedbacks can lead to an increase in net accumulation and promote long-term stability of peat accumulation or persistence under changing climatic conditions (Belyea \& Clymo 2001, Belyea \& Malmer 2004, Strack et al. 2006).
Conceptual representation of SOM pools is also a key difference between models. ECOSSE has 5 SOM pools for the whole profile whereas MILLENNIA calculates annual litter cohorts based on 7 different PFTs, resulting in 3 discrete SOM pools based on litter quality (i.e. lignin, holo-cellulose and soluble carbohydrates) that accumulate in layers every year. By contrast, the Durham Carbon Model has no explicit representation of SOM pool size, as C fluxes are estimated from water table elevation and were initially designed to be determined over shorttime periods to support management decisions. Given the semi-empirical nature of the Durham Carbon Model, variation between this model and the other DMs is more likely due to the specific data used to calibrate the model. In general, decomposition rates based on the proportion of the total mass or $\mathrm{C}$ content present (i.e. as used in ECOSSE) have been argued to be a robust method of representing the intrinsic process of net peat accumulation rather than considering average accumulation rate over a fixed time period (Clymo et al. 1998). The ability to parameterise models explicitly in terms of partitioning total $\mathrm{C}$ lost between different gaseous (i.e. $\mathrm{CO}_{2}$ and $\mathrm{CH}_{4}$ ) and aquatic (i.e. DOC, dissolved inorganic carbon and POC) pathways is still uncertain as few data are available. Integrated research between modellers and experimenters is urgently needed to address this crucial gap in knowledge.

DMs of blanket peatlands are in the early stages of development. Although many SOM models have been developed (e.g. Smith et al. 1997), these have largely been for mineral soils where organic matter contents are typically $<10 \%$, unsaturated conditions prevail and, consequently, temperature effects on decomposition are most important. Model inter-comparison studies represent an important part of model evaluation and development. Differences in predictions between specific models and field data and between models themselves highlight the need for further research to verify, develop and include key process representation within these models (e.g. water table dynamics and the associated feedbacks) and to obtain relevant parameter and calibration data. These differences also highlight the need for caution when interpreting projections from any model. It is also important to remember that the choice of GCM used to generate climate projections can often be the greatest source of uncertainty in climate change impact assessments (Arnell 1999, Graham et al. 2007, Kay et al. 2009).

\section{CONCLUSIONS}

Comparison between 3 DMs and 9 BCEMs at 4 British peatland sites (Auchencorth Moss, Moor House, Bleaklow and Conwy) showed that stability of these blanket peatlands is likely to be vulnerable to pro- 
jected increases in temperature and potential evaporation under future climate change. BCEMs consistently showed a shift away from a climate currently associated with blanket peat presence under future climate projections, with the sites with the lowest total annual precipitation expected to switch from predicted presence to absence earlier than wetter sites. DMs had a more variable response, with ECOSSE predicting a decline in net $\mathrm{C}$ sink and shift to net $\mathrm{C}$ source by the end of this century; the Durham Carbon Model predicting a smaller decline in the net $\mathrm{C}$ sink strength but no consistent shift to net $\mathrm{C}$ source; and MILLENNIA, by contrast, predicting a slight overall increase in the net $\mathrm{C}$ sink. Contrary to the BCEMs, the sites that were most vulnerable to change using DM predictions were the coolest sites with greatest total annual precipitation.

There was reasonable agreement between models on the sign of net C balance (DMs) and prediction of blanket peat presence (BCEMs) during the historic baseline climate period (1960-1989). However, there was considerable difference in both the sign and magnitude of change of the net $\mathrm{C}$ balance in the future between the DMs. This is due to differences in model structure, in particular the differences in the sensitivity to changes in key climate variables. It is not clear which model is 'correct' as there are not enough observed data on past change with which to verify the models. This limits our ability to judge whether BECMs are a suitable proxy for future change in peat $\mathrm{C}$ stocks

This model comparison indicates that British peatlands are likely to be vulnerable to future climate change, but shows that there is still considerable uncertainty regarding the magnitude and timing of changes in C stocks. Because of the large $\mathrm{C}$ stocks in peatlands, climate feedbacks could be considerable and there are consequently clear implications for policy makers and land managers with an interest in climate change mitigation. Therefore, care needs to be taken with the interpretation of predictions from individual models. Simple bioclimatic models only inform us whether the climate under which blanket peats exist today persists into the future. No prediction about the implications of 'change' for $\mathrm{C}$ stocks or other ecosystem properties is made, and no account is taken of inherent feedbacks within the system, particularly the balance between primary production and decomposition. DMs are more complex and contain ecosystem processes. They can account for possible feedbacks but only for those included in their structures. Further research to develop and test the process representation within these models against field observations, and more observational and experimental data to do this, will enable more robust predictions about the stability of blanket peatlands under future climate change.
Acknowledgements. This research was jointly funded by the Environment Agency (Science Project Sc070036) and the NERC QUEST research programme, including support for J.M.C., A.V.G.S. and J.I.H.. J.M.C. was also supported by a fellowship from the Grantham Institute for Climate Change, Imperial College; P.S. is a Royal Society-Wolfson Research Merit Award holder; F.W. was supported by NERC/FREE grant NE/E002242/1; S.C.'s studentship was financed by NERC and model development was partly funded by the UKPopNet (NERC) initiative. The views expressed are those of the authors and do not necessarily represent the position of the funding organisations. We thank the Met Office/UKCP for use of their gridded climate data (www.metoffice.gov. uk/climatechange/science/monitoring/ukcp09/index.html); UK Met Office, Hadley Centre HadRM3-PPE-UK Model Data (http://badc.nerc.ac.uk/data/hadrm3-ppe-uk) for future climate projections; and $M$. Cooper for data for the Conwy catchment. In particular, we thank the EA-QUEST Uplands network for their input in the development of this work at workshops and throughout the duration of the project (http:// quest.bris.ac.uk/research/wkg-gps/soil.html).

\section{LITERATURE CITED}

Adamson JK, Scott WA, Rowland AP (1998) The dynamics of dissolved nitrogen in a blanket peat dominated catchment. Environ Pollut 99:69-77

Adamson JK, Scott WA, Rowland AP, Beard GR (2001) Ionic concentrations in a blanket peat bog in northern England and correlations with deposition and climate variables. Eur J Soil Sci 52:69-79

Allen RG, Pereira LS, Raes D, Smith M (1998) Crop evapotranspiration. Guidelines for computing crop water requirements. FAO Irrigation and Drainage Paper 56, FAO, Rome

Arnell NW (1999) The effect of climate change on hydrological regimes in Europe: a continental perspective. Global Environ Change 9:5-23

Bellamy PH, Loveland PJ, Bradley RI, Lark RM, Kirk GJD (2005) Carbon losses from all soils across England and Wales 1978-2003. Nature 437:245-248

Belyea LR, Clymo RS (2001) Feedback control of the rate of peat formation. Proc R Soc Lond B Biol Sci 268:1315-1321

> Belyea LR, Malmer N (2004) Carbon sequestration in peatland: patterns and mechanisms of response to climate change. Global Change Biol 10:1043-1052

Billett MF, Palmer SM, Hope D, Deacon C, Storeton-West R, Hargreaves KJ, Flechard C, Fowler D (2004) Linking land-atmosphere-stream carbon fluxes in a lowland peatland system. Global Biogeochem Cycles 18:GB1024 doi:1010.1029/2003GB002058

Billett MF, Charman DJ, Clark JM, Evans CD and others (2010) Carbon balance of UK peatlands: current state of knowledge and future research challenges. Clim Res 45: $13-29$

Clark JM, Ashley D, Wagner M, Chapman PJ, Lane SN, Evans CD, Heathwaite AL (2009) Increased temperature sensitivity of net DOC production from ombrotrophic peat due to water table draw-down. Global Change Biol 15: 794-807

Clark JM, Gallego-Sala AV, Allott TEH, Chapman S and others (2010) Assessing the vulnerability of blanket peat to climate change using an ensemble of statistical bioclimatic envelope models. Clim Res 45:131-150

Clymo RS, Turunen J, Tolonen K (1998) Carbon accumulation in peatland. Oikos 81:368-388 
Coleman K, Jenkinson DS (1996) RothC-26.3: a model for the turnover of carbon in soil. Springer-Verlag, Heidelberg

> Daniels SM, Agnew CT, Allott TEH, Evans MG (2008) Water table variability and runoff generation in an eroded peatland, South Pennines, UK. J Hydrol 361:214-226

Dinsmore KJ, Billett MF (2008) Continuous measurement and modeling of $\mathrm{CO}_{2}$ losses from a peatland stream during stormflow events. Water Resour Res 44:W12417 doi:10.1029/ 2008WR007284

Dinsmore KJ, Billett MF, Skiba UM, Rees RM, Drewer J, Helfter C (2010) Role of the aquatic pathway in the carbon and greenhouse gas budgets of a peatland catchment. Global Change Biol 16:2750-2762

> Drewer J, Lohila A, Aurela M, Laurila T and others (2010) Comparison of greenhouse gas fluxes and nitrogen budgets from an ombrotrophic bog in Scotland and a pristine mire in Finland. Eur J Soil Sci 61:640-650

Evans CD, Cooper DM, Juggins S, Jenkins A, Norris D (2006) A linked spatial and temporal model of the chemical and biological status of a large, acid-sensitive river network. Sci Total Environ 365:167-185

Ellis CJ, Tallis JH (2000) Climatic control of blanket mire development at Kentra Moss, north-west Scotland. J Ecol 88:869-889

Evans MG, Burt TP, Holden J, Adamson JK (1999) Runoff generation and water table fluctuations in blanket peat: evidence from UK data spanning the dry summer of 1995. J Hydrol 221:141-160

Evans MG, Lindsay J (2010a) High resolution quantification of gully erosion in upland peatlands at the landscape scale. Earth Surf Process Landf 35:876-886

Evans MG, Lindsay J (2010b) Impact of gully erosion on carbon sequestration in blanket peatlands. Clim Res 45: $31-41$

Freeman C, Evans CD, Monteith DT, Reynolds B, Fenner N (2001a) Export of organic carbon from peat soils. Nature 412:785

Freeman C, Ostle N, Kang H (2001b) An enzymic 'latch' on a global carbon store. Nature 409:149

Friedlingstein P, Cox P, Betts R, Bopp L and others (2006) Climate-carbon cycle feedback analysis: results from the (CMIP)-M-4 model intercomparison. J Clim 19:3337-3353

Frolking S, Roulet NT, Moore TR, Richard PJH, Lavoie M, Muller SD (2001) Modeling northern peatland decomposition and peat accumulation. Ecosystems 4:479-498

Fronzek S, Luoto M, Carter TR (2006) Potential effect of climate change on the distribution of palsa mires in subarctic Fennoscandia. Clim Res 32:1-12

Gallego-Sala AV, Clark JM, House JI, Orr HG and others (2010) Bioclimatic envelope model of climate change impacts on blanket peatland distribution in Great Britain. Clim Res 45:151-162

Garnett MH (1998) Carbon storage in a Pennine moorland and response to change. $\mathrm{PhD}$ thesis, Department of Geography, University of Newcastle-Upon-Tyne

Gorham E (1991) Northern peatlands: role in the carbon cycle and probable responses to climatic warming. Ecol Appl 1:182-195

Graham LP, Hagemann S, Jaun S, Beniston M (2007) On interpreting hydrological change from regional climate models. Clim Change 81:97-122

- Hampe A (2004) Bioclimate envelope models: what they detect and what they hide. Global Ecol Biogeogr 13:469-471

- Hargreaves GL, Hargreaves GH, Riley JP (1985) Irrigation water requirements for Senegal River basin. J Irrig Drain Eng 111:265-275

Heal OW, Smith RAH (1978) Introduction and site description.
In: Heal OW, Perkins DF (eds) Production ecology of British moors and montane grasslands. Springer, Berlin, p 2-16

Heikkinen RK, Luoto M, Araujo MB, Virkkala R, Thuiller W, Sykes MT (2006) Methods and uncertainties in bioclimatic envelope modelling under climate change. Prog Phys Geogr 30:751-777

Heinemeyer A, Croft S, Garnett MH, Gloor E, Holden J, Lomas MR, Ineson P (2010) The MILLENNIA peat cohort model: predicting past, present and future soil carbon budgets and fluxes under changing climates in peatlands. Clim Res 45:207-226

Holden J, Adamson JK (2001) Gordon Manley: an upland meteorological pioneer. J Meteorol 26:369-374

Hossell JE, Briggs B, Hepburn IR (2000) Climate Change and UK Nature Conservation: a review of the impact of climate change on UK species and habitat conservation policy. Department of the Environment, Transport and the Regions, London

House JI, Clark JM, Gallego-Sala AV, Orr HG and others (2010) Vulnerability of upland peatland services to climate change. Environment Agency Science Report SC070036/ SR Draft, Bristol

Hulme M, Jenkins GL, Lu X, Turnpenny JR and others (2002) climate change scenarios for the United Kingdom: the UKCIP02 Scientific Report. Tyndall Centre for Climate Change Research, School of Environmental Sciences, University of East Anglia, Norwich

Ise T, Dunn AL, Wofsy SC, Moorcroft PR (2008) High sensitivity of peat decomposition to climate change through water-table feedback. Nat Geosci 1:763-766

> Jones C, McConnell C, Coleman K, Cox P, Falloon P, Jenkinson D, Powlson D (2005) Global climate change and soil carbon stocks; predictions from two contrasting models for the turnover of organic carbon in soil. Global Change Biol 11:154-166

Kay AL, Davies HN (2008) Calculating potential evaporation from climate model data: A source of uncertainty for hydrological climate change impacts. J Hydrol 358: 221-239

Kay AL, Davies HN, Bell VA, Jones RG (2009) Comparison of uncertainty sources for climate change impacts: flood frequency in England. Clim Change 92:41-63

Leith H, Box E (1972) Evapotranspiration and primary productivity: Thornthwaite Memorial Model. Publ Climatol $25: 37-46$

Limpens J, Berendse F, Blodau C, Canadell JG and others (2008) Peatlands and the carbon cycle: from local processes to global implications - a synthesis. Biogeosciences 5:1475-1491

Lindsay RA (1995) Bogs: the ecology, classification and conservation of ombrotrophic mires. Scottish Natural Heritage, Battleby

Lindsay RA, Charman DJ, Everingham F, O'Reilly RM, Palmer MA, Rowell TA, Stroud DA (1988) The Flow Country: the peatlands of Caighness and Sutherland. Nature Conservancy Council, Peterborough

Maraun D, Wetterhall F, Ireson AM, Chandler RE and others (2010) Precipitation downscaling under climate change. Recent developments to bridge the gap between dynamical models and the end user. Rev Geophys doi:10.1029/ 2009RG000314

Milne R, Brown TA (1997) Carbon in the vegetation and soils of Great Britain. J Environ Manag 49:413-433

Monteith DT, Stoddard JL, Evans CD, de Wit HA and others (2007) Dissolved organic carbon trends resulting from changes in atmospheric deposition chemistry. Nature 450: $537-540$ 
Moore TR, Roulet NT, Waddington JM (1998) Uncertainty in predicting the effect of climatic change on the carbon cycling of Canadian peatlands. Clim Change 40:229-245

Morin X, Thuiller W (2009) Comparing niche- and processbased models to reduce prediction uncertainty in species range shifts under climate change. Ecology 90: 1301-1313

Murphy J, Sexton D, Jenkins G, Boorman P and others (2009) UK Climate Projections science report: climate change projections. Met Office Hadley Centre, Exeter

Nakicenovic N, Alcamo J, Davis G, de Vries B and others (2000) Special Report on Emissions Scenarios: a Special Report of Working Group III of the Intergovernmental Panel on Climate Change. Cambridge University Press, Cambridge

Pearsall WH (1950) Mountains and moorlands. Collins, London

Pearsall WH (1965) Mountains and moorlands. Bloomsberry Books, London

Perry M, Hollis D (2005) The generation of monthly gridded datasets for a range of climatic variables over the UK. Int J Climatol 25:1041-1054

Prentice IC, Bondeau A, Cramer W, Harrison SP and others (2007) Dynamic global vegetation modelling: quantifying terrestrial ecosystem responses to large-scale environmental change. In: Canadell JG, Pitelka L, Pataki D (eds) Terrestrial ecosystems in a changing world. SpringerVerlag, Berlin, p 175-192

Priestley CHB, Taylor RJ (1972) Assessment of surface heat flux and evaporation using large scale parameters. Mon Weather Rev 100:81-92

Qian HF, Joseph R, Zeng N (2010) Enhanced terrestrial carbon uptake in the northern high latitudes in the 21st century from the Coupled Carbon Cycle Climate Model Intercomparison Project model projections. Global Change Biol 16:641-656

Ramchunder SJ, Brown LE, Holden J (2009) Environmental effects of drainage, drain-blocking and prescribed vegetation burning in UK upland peatlands. Prog Phys Geogr 33:49-79

Randerson JT, Hoffman FM, Thornton PE, Mahowald NM and others (2009) Systematic assessment of terrestrial biogeochemistry in coupled climate-carbon models. Glob Change Biol 15:2462-2484

R Development Core Team (2008) R: a language and environmnet for statistical computing. R Foundation for Statistical Computing, Vienna

Submitted: August 24,2010; Accepted: November 12, 2010
Smith P (2001) Soil organic matter modeling. In: Lal R (ed) Encyclopedia of soil science. Marcel Dekker, New York

Smith P, Fang C (2010) Carbon cycle: a warm response by soils. Nature 464:499-500

Smith P, Smith JU, Powlson DS, McGill WB and others (1997) A comparison of the performance of nine soil organic matter models using datasets from seven long-term experiments. Geoderma 81:153-225

Smith P, Smith J, Flynn H, Killham K and others (2007) ECOSSE: Estimating Carbon in Organic Soils Sequestration and Emission. Scottish Exectuive, Edinburgh

Smith JU, Gottschalk P, Bellarby J, Chapman S and others (2010a) Estimating changes in Scottish soil carbon stocks using ECOSSE. I. Model description and uncertainties. Clim Res 45:179-192

Smith JU, Gottschalk P, Bellarby J, Chapman S and others (2010b) Estimating changes in Scottish soil carbon stocks using ECOSSE. II. Application. Clim Res 45:193-205

Strack M, Waddington JM, Rochefort L, Tuittila ES (2006) Response of vegetation and net ecosystem carbon dioxide exchange at different peatland microforms following water table drawdown. J Geophys Res 111:G02006

Sykes MT, Prentice IC, Cramer W (1996) A bioclimatic model for the potential distributions of north European tree species under present and future climates. J Biogeogr 23: 203-233

Tallis JH (1994) Pool-and-hummock patterning in a Southern Pennine blanket mire. II. The formation and erosion of the pool system. J Ecol 82:789-803

Thornthwaite CW (1948) An approach toward a rational classification of climate. Geogr Rev 38:55-94

Thornthwaite CW, Mather JR (1955) The water balance. Climatology 8:1-104

- Vitt DH, Halsey LA, Bauer IE, Campbell C (2000) Spatial and temporal trends in carbon storage of peatlands of continental western Canada through the Holocene. Can J Earth Sci 37:683-693

Wieder RK, Vitt DH (2006) Boreal peatland ecosystems. Springer, Berlin

- Worrall F, Burt T (2005) Predicting the future DOC flux from upland peat catchments. J Hydrol (Amst) 300:126-139

Worrall F, Burt TP, Rowson JG, Warburton J, Adamson JK (2009a) The multi-annual carbon budget of a peat-covered catchment. Sci Total Environ 407:4084-4094

- Worrall F, Evans MG, Bonn A, Reed MS, Chapman D, Holden $\mathrm{J}$ (2009b) Can carbon offsetting pay for upland ecological restoration? Sci Total Environ 408:26-36

Proofs received from author(s): December 14, 2010 